\title{
New Occurrence of Gold Mineralization at the Eastern Part of Wadi El Gemal, South Eastern Desert, Egypt
}

\author{
Mohamed Salem Kamar \\ Nuclear Materials Authority, El Maadi, Cairo, Egypt \\ Email: drkamar30@gmail.com
}

How to cite this paper: Kamar, M.S. (2020) New Occurrence of Gold Mineralization at the Eastern Part of Wadi El Gemal, South Eastern Desert, Egypt. Open Journal of Geology, 10, 1210-1233.

https://doi.org/10.4236/ojg.2020.1012060

Received: November 11, 2020

Accepted: December 26, 2020

Published: December 29, 2020

Copyright ( 2020 by author(s) and Scientific Research Publishing Inc. This work is licensed under the Creative Commons Attribution International License (CC BY 4.0).

http://creativecommons.org/licenses/by/4.0/

\section{(c) (i) Open Access}

\begin{abstract}
The basement rock units of the study area are represented by metasedimentsmetavolcanics association, diorite rocks, granodiorites and syenogranites. The whole sequence is cut by basic dykes, pegmatites and different quartz (jasper) veins. Metasediments-metavolcanics association is represented by hornblende schist and metadacite respectively. There is visible sulfides mineralization in hornblende schist, metadacite and diorite rocks at their contacts at the wadi level. So, polished sections were prepared to study opaque minerals under the ore microscope, which reveals the presence of gold, pyrite and goethite. The radioactivity of this area is weak, where the average eU contents in metasediments-metavolcanics association, diorites, granodiorites, syenogranites, pegmatites and jasper veins are $2.8 \mathrm{ppm}, 1.9 \mathrm{ppm}, 3.26 \mathrm{ppm}, 4.91 \mathrm{ppm}, 4.32$ $\mathrm{ppm}$ and $6.7 \mathrm{ppm}$ respectively. The intrusion of granodiorite rocks may act as a source for hydrothermal solutions ascending along fractures of all older rocks. During this stage, a chemical reaction of hydrothermal fluids with metasediments-metavolcanics association and diorite rocks lead to forming sericite and enrichment of silica content. The enrichment of silica content led to the formation of quartz-diorite. Also, iron derived from the host rocks and sulfur from the hydrothermal fluids could have formed pyrite while the gold was precipitated at the contact between metasediments-metavolcanics association and diorite rocks.
\end{abstract}

\section{Keywords}

Wadi El Gemal, Gold, Metasediments-Metavolcanics Association, Diorite, Egypt

\section{Introduction}

There are more than 100 locations for gold mining in the Eastern Desert of 
Egypt. These locations were spread over the whole area covered by the Precambrian basement rocks. Hume (1937) [1], interprets gold mineralization as integral part of hydrothermal processes related to dioritic intrusions of Proterozoic age or related to the Gattarian granites of Late Proterozoic-Early Paleozoic age [2] [3]. The other theory maintains that gold mineralization is multi-aged and related to general tectonic-magmatic stages [4] [5] [6]. Sabet and Bordonosov (1984) [7] classified gold deposits in Egypt into three formations namely gold-sulphide formation, skarn gold-ferruginous quartzite formation and gold quartz formation. Although this classification is the first actual attempt at classifying gold deposits in Egypt, it ignores the tectonic setting of host rocks, as well as the source of the mineralizing fluids.

A few studies have focused on the geochemical prospecting pattern and primary haloes of gold [8] [9] [10]. The vast majority of the Egyptian gold deposits belong to the orogenic vein type [11] [12] [13] [14]. Most of the auriferous veins are confined to granitic plutons that intruded metamorphosed ophiolite and/or arc-related rock assemblages [15]-[20]. Metamorphic hydrothermal fluids have been suggested as the main transporting fluids, whereas mafic/ultramafic ophiolitic rocks have been postulated as the main source of gold [18] [21]-[29]. Zoheir et al. (2019) [29] concluded that gold occurrences in granitoid-gabbroid domains are controlled by fault and brittle shear zones assigned as antithetic sets in a rejuvenated transpression-transtension regime operated intermittently from the orogenic collision to orogen collapse.

Wadi (W.) El Gemal lies at about $50 \mathrm{~km}$ south of Marsa Alam City, south Eastern Desert (SED) of Egypt and is included in protected area. The geological importance of W. El Gemal gets from its tributaries (Um Kabu, Umm Addebaa, Nugrus, Sikait, and Abu Rusheid). So, Most of the researchers focused on these tributaries and little attention to the wadi itself. Some authors studied the rocks of the area between W. El Gemal and W. Ghadir ([30] [31] [32]) and all of these studies are not in detail for the present area of study.

The study area is located in the eastern part of W. El Gemal between latitudes $24^{\circ} 34^{\prime} 06^{\prime \prime}$ to $24^{\circ} 39^{\prime} 13^{\prime \prime} \mathrm{N}$ and longitudes $34^{\circ} 58^{\prime} 41^{\prime \prime}$ to $35^{\circ} 03^{\prime} \mathrm{E}$ (Figure 1 ).

The present study throws light on the geological and mineralogical aspects of this area and focuses on the new occurrence of gold mineralization. So, geological map was constructed and collected samples from different rock types, then thin and polished sections were made for petrographic and ore microscopic studies. Also, the separated minerals were identified by Scanning Electron Microscope (SEM) in addition to fire assay techniques for the determination of gold concentration.

\section{Geological Setting}

The basement rocks exposed in the eastern side of W. El Gemal area are metasediments-metavolcanics association, diorite rocks, older granitoids (granodiorite) and younger granites (syenogranites). All the previously mentioned 


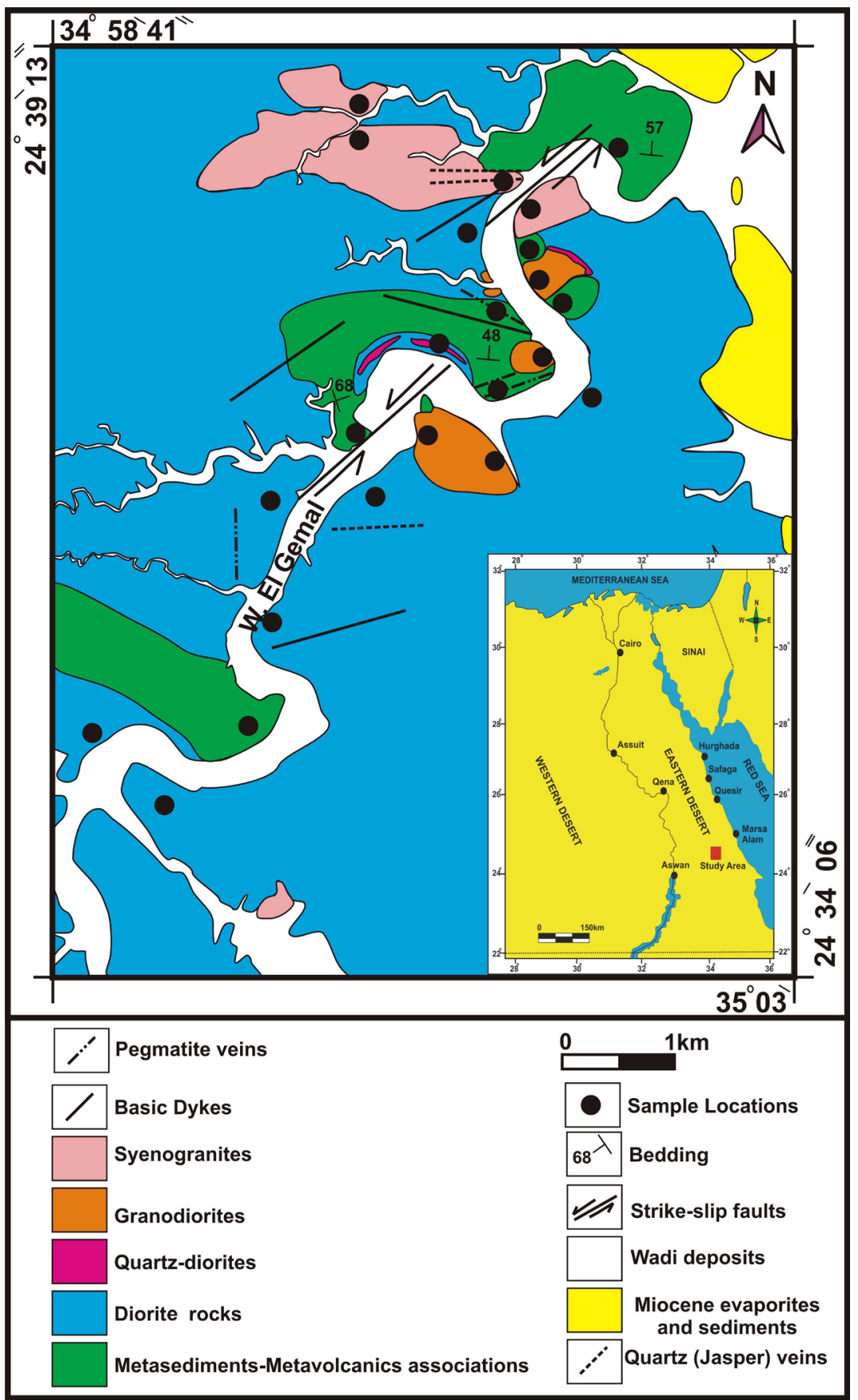

Figure 1. Geological map of the eastern part of Wadi El Gemal area, south Eastern Desert, Egypt (modified after [31]).

rock units are invaded by pegmatite and basic dykes as well as quartz veins (Figure 1). These rocks form moderate terrains. The intercalation of metasediments and metavolcanics is a dominant character in the Egyptian Shield [33] [34] [35]. The metasediments are represented by hornblende schist that intercalated with metavolcanics, which represented by metadacite. The bedding planes are $45^{\circ}-70^{\circ} / \mathrm{N}-\mathrm{E}$ and the foliations are developed and have nearly the same attitudes (Figure 2). These rocks are intruded by the diorites, granodiorites (Figure 3) 


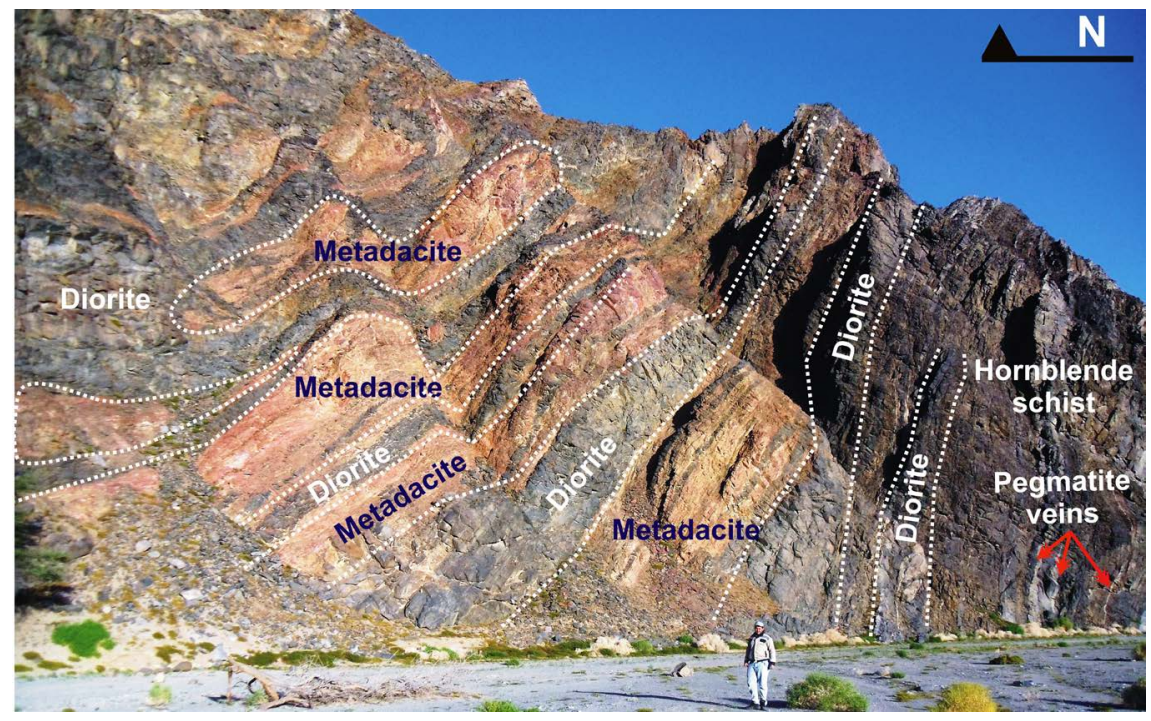

Figure 2. General view of foliated and bedded metasediments-metavolcanics association intruded by diorite rocks.

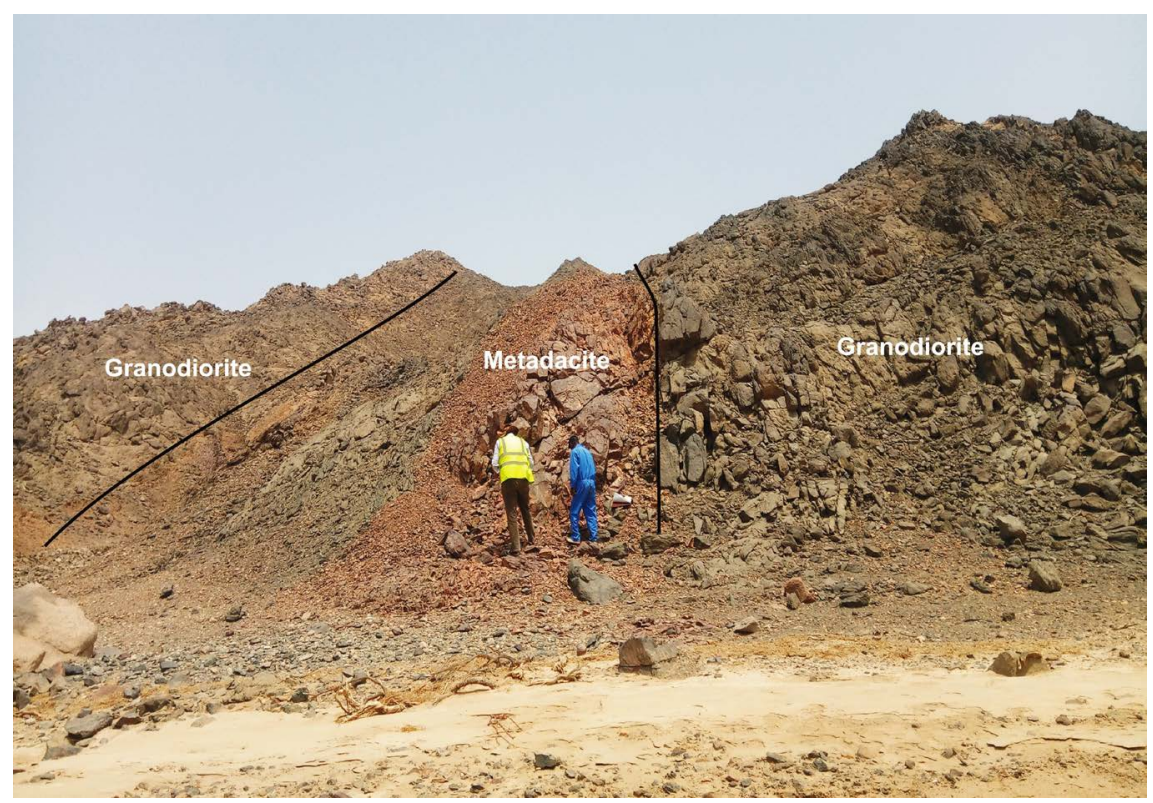

Figure 3. View showing metadacite as roof pendants in granodiorite, looking E.

and syenogranites with intrusive sharp contacts. They are frequently dissected by basic dykes, pegmatite veins and sometimes folded (Figure 4). The metasediments-metavolcanics are enriched with sulphides and gold minerals. They are highly weathered, jointed and dissected by strike-slip faults.

The diorite rocks of the gabbro, diorite complex are dark green to greyish green in colour and medium, to coarse-grained. The rocks cover most of the study area along the two sides of W. El Gemal and sometimes occur as xenoliths or as roof pendants uplifted by the syenogranites. The rocks are characterized by heterogeneous nature marked by variations in grain size and in the proportion of mafic and felsic minerals. 


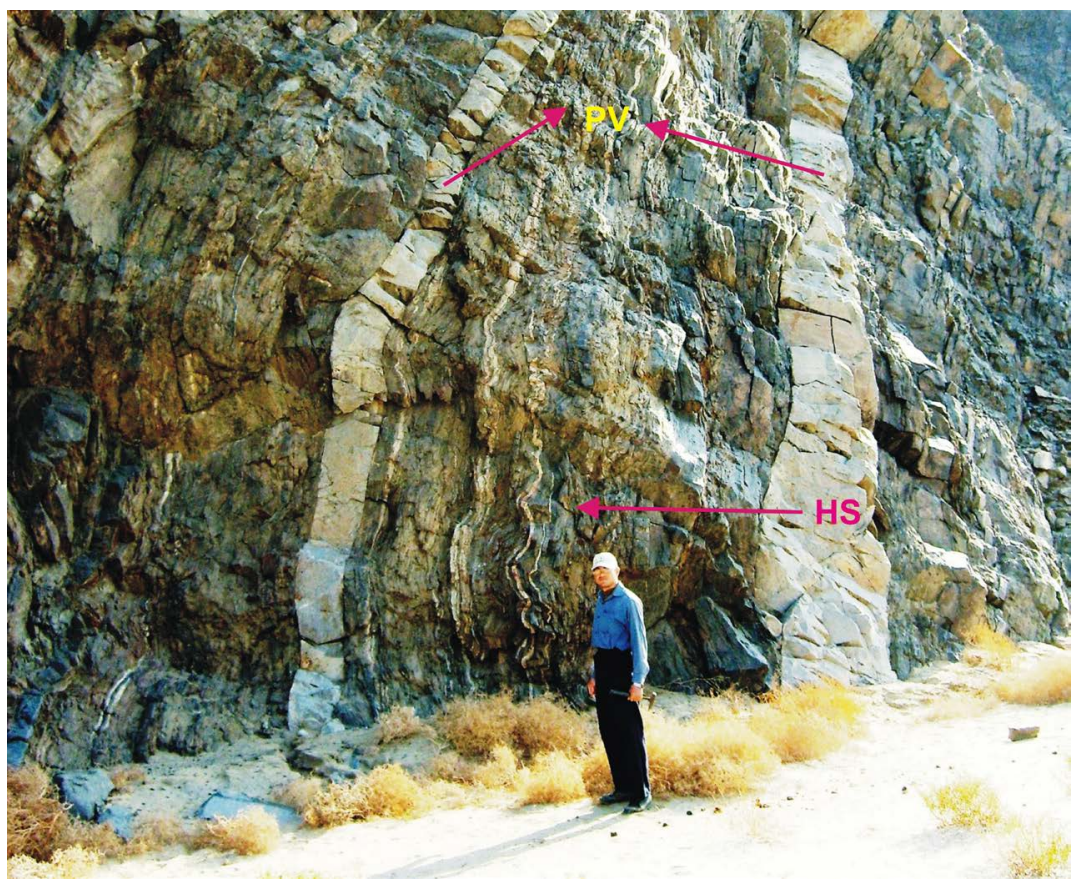

Figure 4. View showing folded hornblende schist (HS) invaded by pegmatite veins (PV), conformable with the bedding planes, looking NE.

They are characterized by low to moderate relief terrains. They are dissected by strike-slip fault and show sharp contact with metasediments-metavolcanics association, as well as syenogranite and sometimes contain xenoliths from older rocks (Figure 5). The quartz-diorites exist as small masses associated with diorite rocks especially in zones rich by sulphides and gold mineralization.

The older granitoids are represented by granodiorites (Figure 3). These rocks form moderate relief and they are hard, massive and medium- to coarse-grained with grey colour. It sometimes shows cavernous, exfoliation weathering and blocky appearance. Mafic microgranular enclaves are frequently hosted in the pluton of older granitoids. These enclaves attain variable dimensions (few centimetres up to $20 \mathrm{~cm}$ of long axes) and variable shapes ranging from subrounded, oval and elongated to irregular forms.

The younger granites of the study area are represented by syenogranites. The rocks are medium-to coarse-grained with pink colour forming medium to high relief mountain terrains. They show cavernous and exfoliation weathering and the characteristic highly jointing. Along of these joints, copper mineralizations as well as pegmatite veins are encountered. Some fractures exhibit high alteration products represented by hematization. Syenogranites contain some xenoliths of older rocks (Figure 6) and intrude all the previously mentioned rock units with sharp intrusive contacts. Apophyses and offshoots of the younger granites are observed into the country rocks.

The dykes are represented by single basic dykes and represent the latest phases of magmatism. They are vertical or steeply inclined sheets injected into all the previously mentioned rocks. They vary in width from $0.5 \mathrm{~m}$ up to $2 \mathrm{~m}$. 


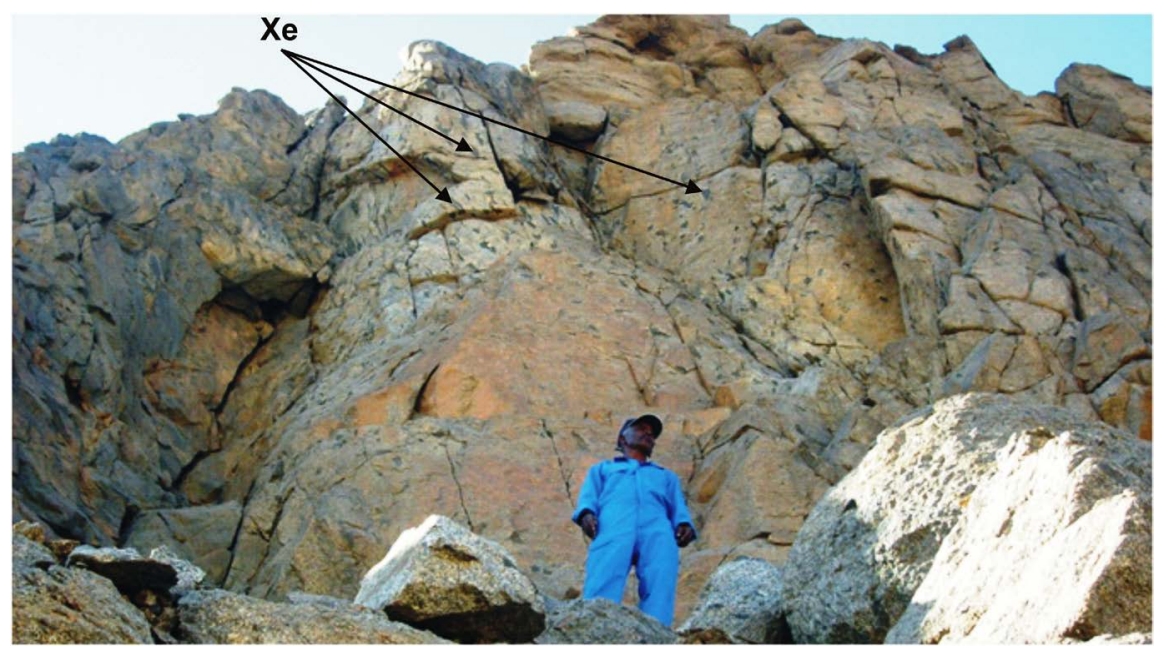

Figure 5. View showing diorite rock contains xenoliths (Xe) from older rocks, Looking SW.

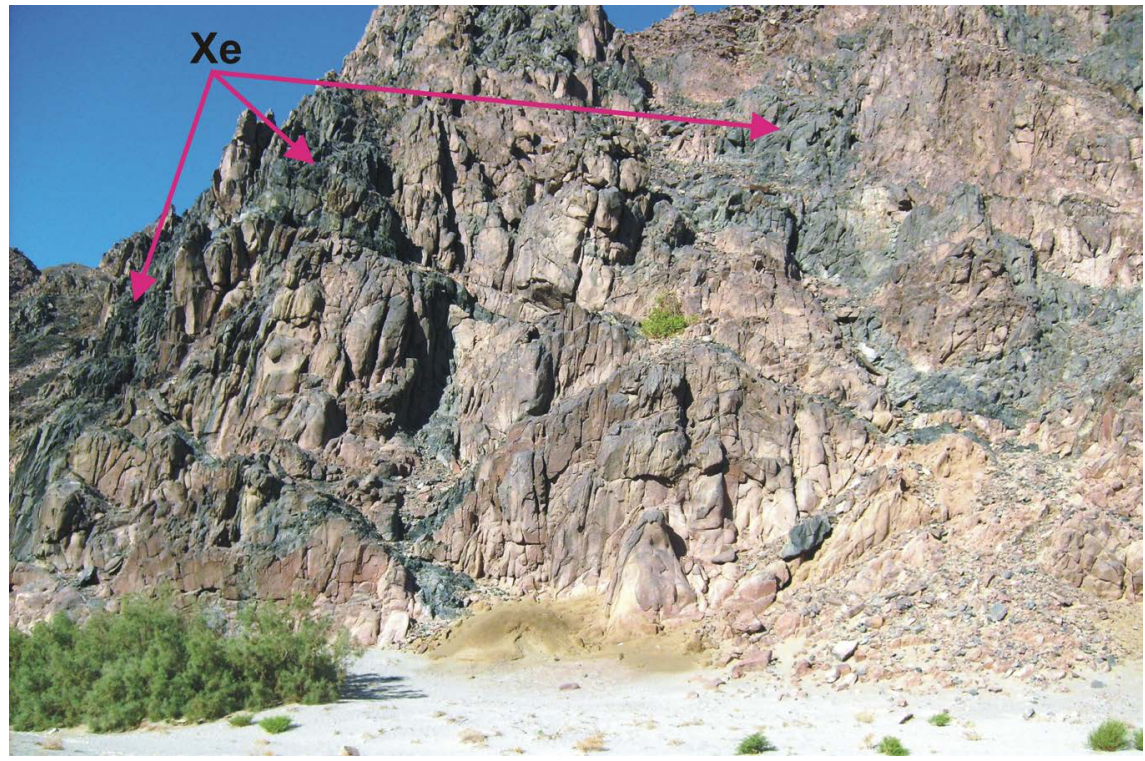

Figure 6. View showing subvertical jointing in syenogranites with xenoliths (Xe) from older rocks, looking $\mathrm{W}$.

The quartz or jasper veins cutting all the previously mentioned rocks and striking E-W and vary in thickness from $0.2 \mathrm{~m}$ up to $2 \mathrm{~m}$ (Figure 7). These jasperoid veins have a relatively higher radioactivity than the hosting rocks especially those in syenogranite.

The pegmatites, striking in different directions (N-S, NE-SW and NW-SE) and cutting all the previously mentioned rocks (Figure 8) and varies in thickness from $5 \mathrm{~cm}$ up to $1.5 \mathrm{~m}$. Visible sulphides mineralization are observed in these pegmatite especially those striking NE-SW.

\section{Petrographic Studies}

The petrographic study was performed through choosing five samples from 


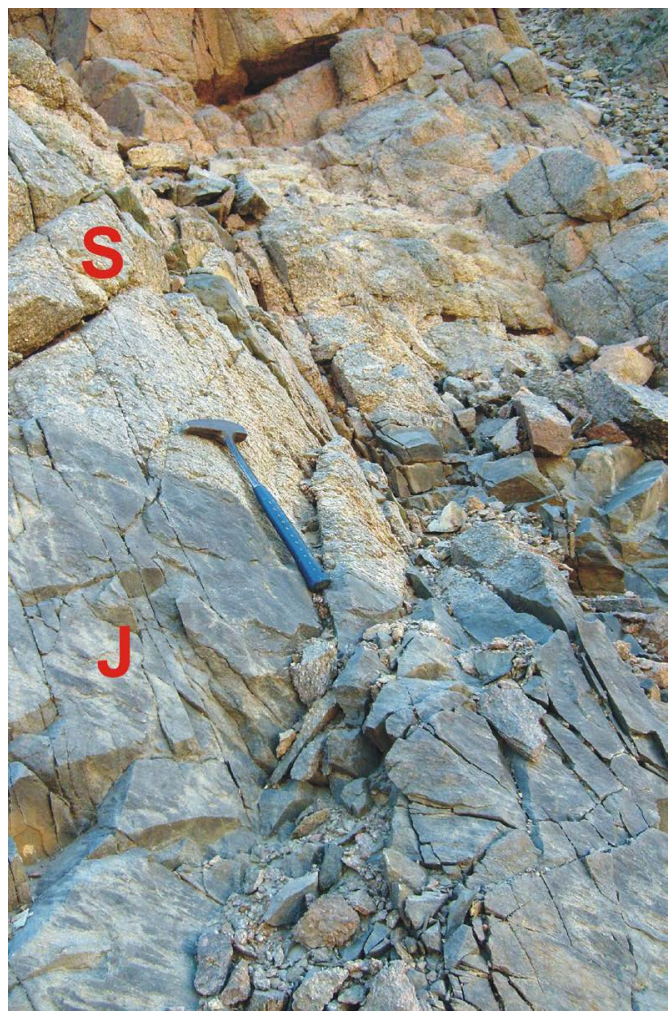

Figure 7. Close up view showing jasper (J) vein cutting syenogranites $(\mathrm{S})$ rock, looking S.

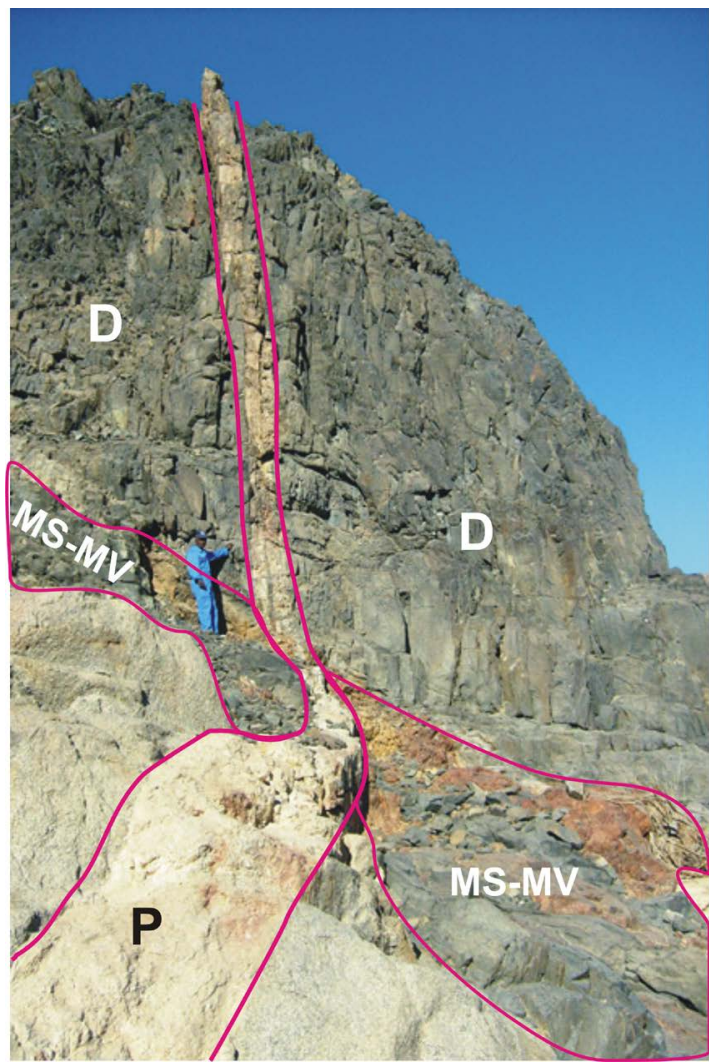

Figure 8. Pegmatite $(\mathrm{P})$ vein cutting metasediments-metavolcanic association (MS-MV) and diorite rock $(\mathrm{D})$, looking $\mathrm{S}$. 
metasediments (hornblende schist), metavolcanics (metadacite) and diorite rocks and four samples from granodiorites and syenogranites rocks. This was carried out at the laboratories of Nuclear Materials Authority (NMA).

Hornblende schist is essentially composed of quartz, hornblende, plagioclase and K-feldspar with opaques as accessory minerals. Quartz occurs as subhedral to anhedral crystals showing undulose extinction. It exhibits irregular boundaries due to recrystallization and deformation. Hornblende occurs as subhedral elongated green crystals. It exhibits simple twinning and associated with opaques and arranged forming schistose texture (Figure 9(a)). Plagioclase exists as subhedral crystals $(0.2 \times 0.4 \mathrm{~mm}$ across $)$, and varies in composition from albite to oligoclase $\left(\mathrm{An}_{8-19}\right)$ and shows both of albite and combined albite/Carlsbad twinning. It exhibits partial alteration to saussurite. K-feldspar occurs as subhedral crystal $(0.2 \times 0.3 \mathrm{~mm}$ across $)$ and represented by orthoclase crystals. It is altered to fine dusty kaolinite. Opaques occur as anhedral crystals associated with hornblende.

Metadacite is composed essentially of plagioclase, quartz, K-feldspar and biotite. Titanite, opaques and epidote existed as accessory minerals. Plagioclase presents as euhedral to subhedral phenocrysts and as fine-grained groundmass of oligoclase and andesine in composition $\left(\mathrm{An}_{18-37}\right)$. It shows albite and pericline twinning and altered to saussurite. Quartz exists as subhedral to anhedral crystals $1.2 \times 2.4 \mathrm{~mm}$ and show undulose extinction due to cataclastic effect. K-feldspar

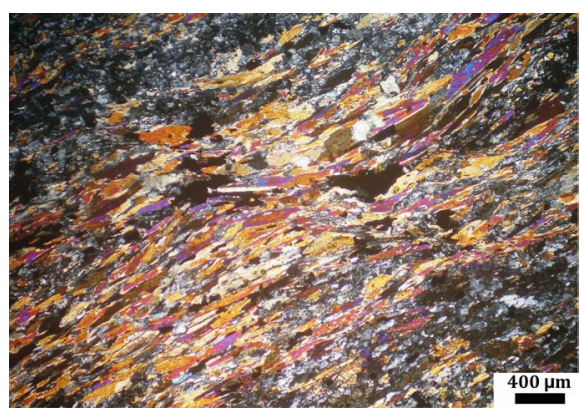

(a)

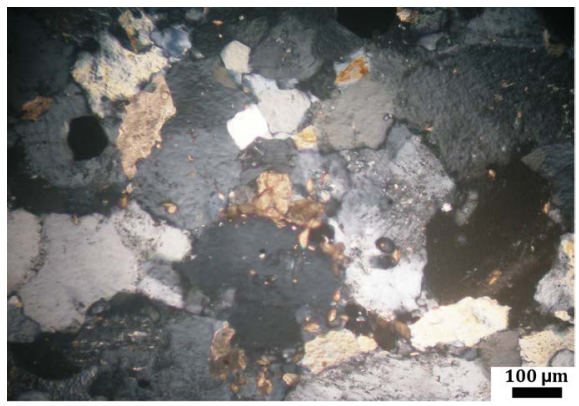

(c)

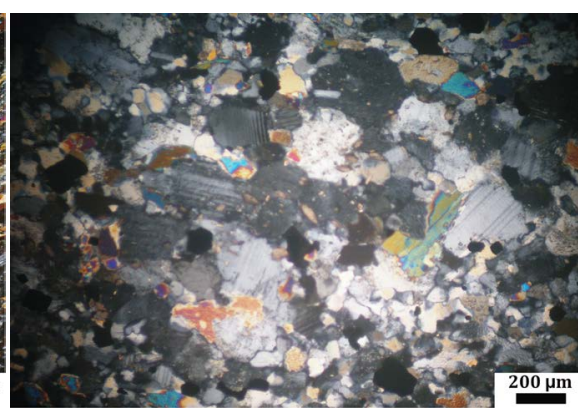

(b)

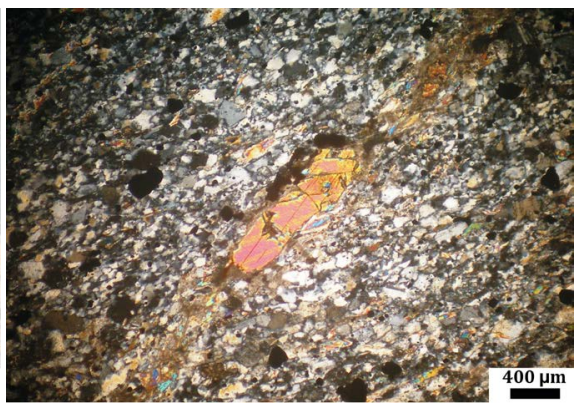

(d)

Figure 9. (a) Photomicrograph showing foliated hornblende forming schistosity in hornblende schist, C.N. (b) Photomicrograph showing fine flakes of biotite associating plagioclase and strained quartz in metadacite, C.N. (c) Photomicrograph showing titanite surrounded by opaques and biotite in metadacite, C.N. (d) Photomicrograph showing oriented porphyroblast of epidote surrounded by quartz and opaques in metadacite, C.N. 
occurs as subhedral phenocrysts and represented by orthoclase and orthoclase microperthite. It is sometimes suffer partial to complete kaolinitization. Biotite occurs as subhedral phenocrysts and sometimes as fine -grained groundmass associating with plagioclase and opaques (Figure 9(b)). It shows partial alteration to chlorite and iron oxides starting from the crystal boundaries. Titanite exists as subhedral crystal surrounded by opaques and biotite (Figure 9(c)). Opaques occur as subhedral to anhedral fine crystals in association with mafic minerals. Epidote occurs as anhedral to subhedral phenocrysts associating opaques and biotite (Figure 9(d)).

The diorite rocks are essentially composed of plagioclase (63\%), mafic minerals (hornblende and biotite) (29\%), K-feldspar (5\%) and quartz (3\%). Apatite, epidote and opaques are accessory minerals. Plagioclase occurs as euhedral to subhedral crystals reaching up to $2.0 \times 3.5 \mathrm{~mm}$ across and varies in composition from oligoclase to andesine $\left(\mathrm{An}_{20-40}\right)$. Some plagioclase crystals are zoned and altered to sericite and also sometimes corroded indicating disequilibrium conditions. Hornblende forms subhedral prismatic crystals and is associated with plagioclase and opaque (Figure 10(a)). Biotite is reddish-brown in colour and forms discrete anhedral to subhedral flakes associated with amphibole. K-feldspar existed as euhedral crystals, whereas quartz occurs as interstitial anhedral crystals and shows undulatory extinction with sutured outlines. The rock contains traces apatite exists as long prismatic crystals associated with plagioclase and opaques. Epidote occurs as anhedral crystals associating opaques and plagioclase. Opaques present as euhedral to subhedral crystals associated with plagioclase and hornblende.

The granodiorite is essentially composed of plagioclase (47\%), quartz (22\%), K-feldspar (18\%), biotite (8\%) and hornblende (5\%). Plagioclase varies in composition from oligoclase to andesine. It occurs usually as subhedral and euhedral crystals, partially and completely altered to sericite. It exhibits albite and combined albite/pericline and albite/Carlsbad twining. The corrosion of K-feldspar to plagioclase develops worm-like quartz grains forming myrmekitic texture. Quartz occurs as subhedral to anhedral crystals filling the interstitial spaces between other minerals. In few cases quartz crystals show undulose extinction and granulated boundaries. K-feldspar forms subhedral to anhedral crystals and is represented mainly by microcline perthite. It is fractured and slightly altered to kaolinite. Myrmekitic texture is occasionally present due to the replacement of plagioclase by K-feldspar. Biotite is the dominant mafic mineral and occurs as euhedral to subhedral crystals. Alteration of biotite to chlorite and iron oxides is observed and usually starts along the cleavage plane. Hornblende occurs as subhedral to euhedral, tabular (Figure 10(b)) and prismatic crystals, partially altered to chlorite and iron oxides. Sometimes, it poikilitically encloses quartz, titanite and apatite. Titanite occurs as primary rhombic euhedral to subhedral crystals and secondary embedded opaques suggesting that these titanite crystals are formed after ilmenite. It is associated with biotite, hornblende, apatite and 


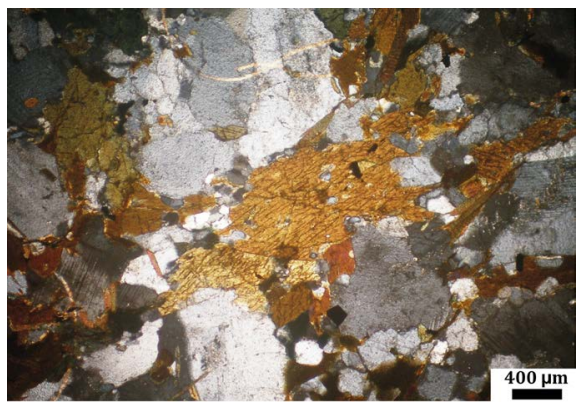

(a)

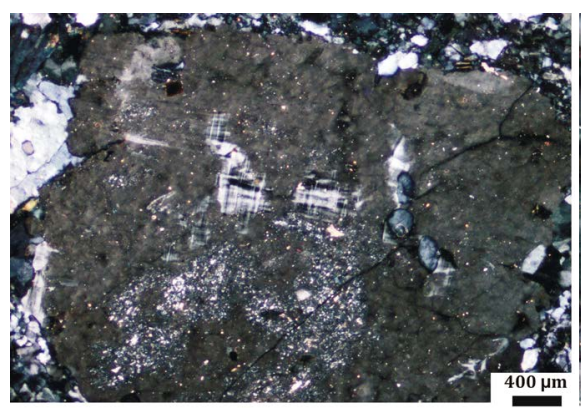

(c)

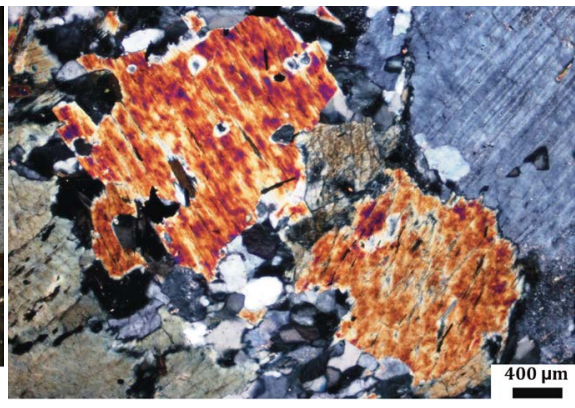

(b)

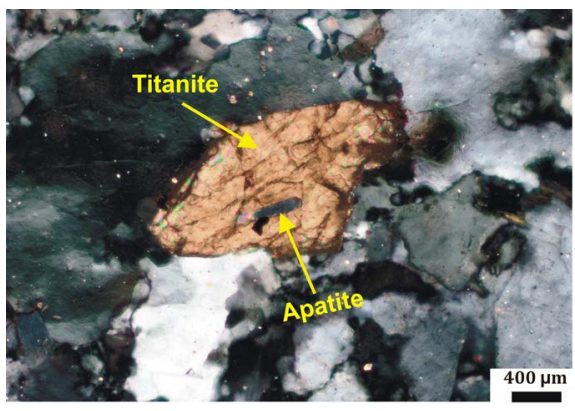

(d)

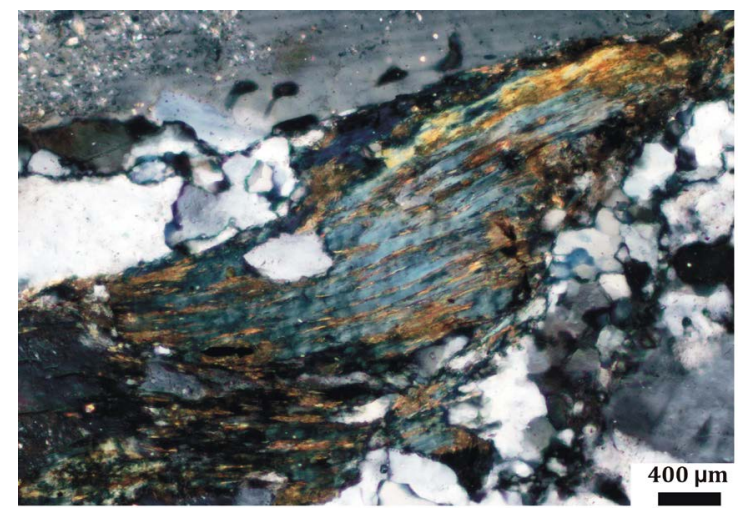

(e)

Figure 10. (a) Photomicrograph showing basal crystal of hornblende associated with plagioclase and opaques in diorite rocks, C.N. (b) Photomicrograph showing hornblende (basal and longitudinal) crystals associated with plagioclase in granodiorite, C.N. (c) Photomicrograph showing partially silicified microcline perthite in syenogranites, C.N. (d) Photomicrograph showing titanite with sphenoidal form enclosing fine crystal of apatite in syenogranites, C.N. (e) Photomicrograph showing kinked flake of chlorite of penninite type in syenogranites, C.N.

opaques. Apatite exists as long prismatic crystals associated with biotite, hornblende and titanite. Opaques occur as euhedral to subhedral crystals embedded within mafic minerals or as discriminated grains.

Syenogranite is essentially composed of K-feldspar (56\%) that occurs as subhedral to anhedral crystals. K-feldspar is represented by orthoclase microperthite and microcline microperthite, which sometimes partially silicified (Figure $10(c))$. String perthite is dominated and fine crystals of plagioclase are poikilitically enclosed in it. Sometimes it is altered to kaolinite and poikilitically encloses 
quartz and opaque. Quartz (25\%) occurs as subhedral to anhedral crystals and interstitial grains between feldspar crystals. It exhibits undulose extinction. Some crystals of quartz are included in microperthite. Plagioclase (15\%) occurs as euhedral to subhedral elongated crystals. It has albite to oligoclase composition $\left(\mathrm{An}_{8-16}\right)$ and exhibits albite and combined albite and pericline twinning. Plagioclase crystals sometimes zoned and show partial sericitization. The corrosion of K-feldspar to plagioclase develops worm-like quartz grains forming myrmekitic texture. The presence of two feldspars (perthite and plagioclase) suggests that this granite is mostly subsolvus and crystallized under high water pressure [36]. Biotite (4\%) occurs as euhedral to subhedral elongate to flakey crystals. It is corroded by quartz and microperthite and shows intensive alteration to chlorite. Zircon occurs as euhedral to subhedral prismatic crystals. It attains pleochroic haloes due to radiogenic effects and associated with biotite and chlorite. Apatite occurs as euhedral prismatic crystals in association with biotite and sometimes enclosed in titanite (Figure 10(d)). Titanite forms subhedral to anhedral rhombic crystals and associated with biotite and apatite. Opaques occur as subhedral to anhedral crystals usually associated with mafic constituents. Chlorite (penninite type) occurs as secondary products after biotite and sometimes kinked (Figure 10(e)).

\section{Radiometric Measurements}

The instrument used in the ground $\gamma$-ray spectrometric survey measurements is RS-230. Ground $\gamma$-ray spectrometric survey can detect dose rate (D.R.) in unit (nano sieverts per hour $\left(\mathrm{nSvh}^{-1}\right)$ ), potassium $(\mathrm{K} \%)$, equivalent uranium content (eU ppm), and equivalent thorium content (eTh ppm). The minimum, maximum and average of the radioactive elements for the studied rock types were listed in Table 1. The uranium concentration increases from diorites (av. $=1.9$ $\mathrm{ppm})$ to metasediments-metavolcanics association (av. $=2.8 \mathrm{ppm})$ to older granites $(\mathrm{av} .=3.26 \mathrm{ppm})$ to pegmatite vein $(\mathrm{av} .=4.32 \mathrm{ppm})$ to younger granites $(4.91 \mathrm{ppm})$ and finally to jasper veins (av. $=6.7 \mathrm{ppm})($ Table 1 and Figure 11$)$.

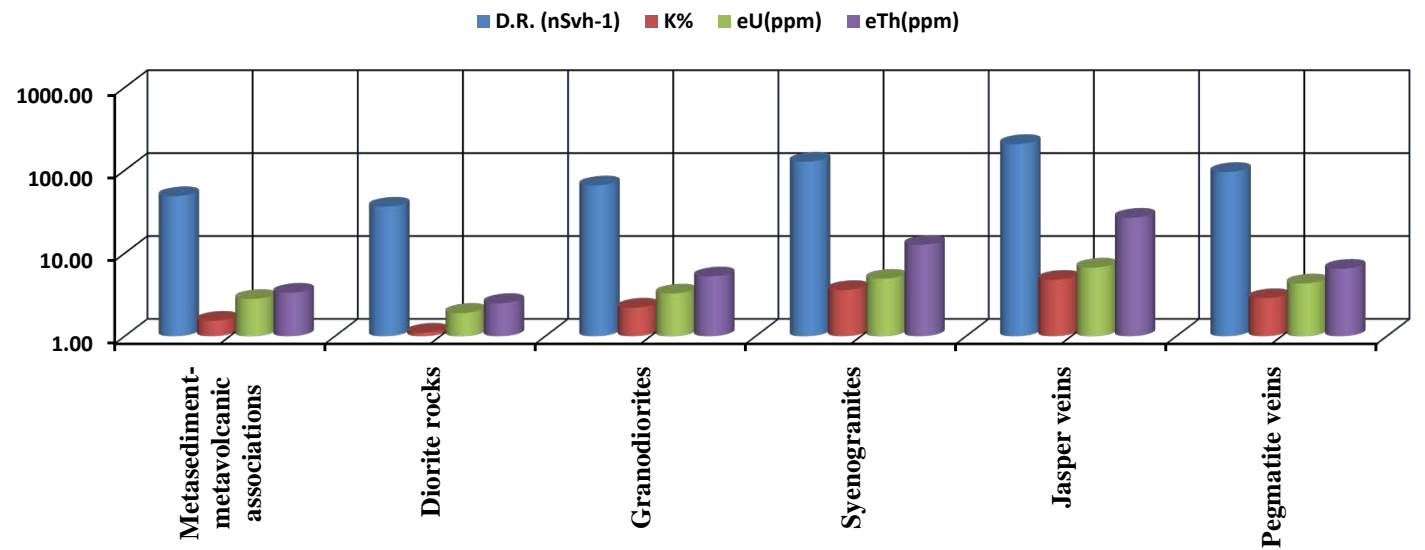

Figure 11. Bar-diagram showing the average concentration of radiometric elements in the different rock types, W. El Gemal area, SED, Egypt. 
Table 1. llustrated the minimum, maximum and the average of the different radiometric elements in the different rock types, W. El Gemal area, SED, Egypt.

\begin{tabular}{|c|c|c|c|c|c|}
\hline Rock Type & & D.R. $\left(\mathrm{nSvh}^{-1}\right)$ & $\mathrm{K} \%$ & $\mathrm{eU}(\mathrm{ppm})$ & eTh (ppm) \\
\hline Metasediments-metavolcanics & Mini & 35.8 & 1.2 & 1.3 & 2.8 \\
\hline \multirow{2}{*}{$\begin{array}{c}\text { Association } \\
(n=6)\end{array}$} & Max & 60.8 & 1.8 & 3.7 & 3.7 \\
\hline & Average & 48.77 & 1.53 & 2.8 & 3.33 \\
\hline \multirow{3}{*}{$\begin{array}{l}\text { Diorite rocks } \\
\qquad(n=6)\end{array}$} & Mini & 20.5 & 0.5 & 0.5 & 1.5 \\
\hline & $\operatorname{Max}$ & 45.8 & 1.5 & 2.5 & 2.9 \\
\hline & Average & 36.4 & 1.1 & 1.9 & 2.5 \\
\hline \multirow{3}{*}{$\begin{array}{l}\text { Granodiorites } \\
\qquad(\mathrm{n}=7)\end{array}$} & Mini & 39.8 & 1.3 & 1.5 & 2.9 \\
\hline & Max & 90.5 & 3.2 & 4.3 & 9.1 \\
\hline & Average & 65.72 & 2.2 & 3.26 & 5.24 \\
\hline \multirow{3}{*}{$\begin{array}{l}\text { Syenogranites } \\
\qquad(\mathrm{n}=15)\end{array}$} & Mini & 97.5 & 2.4 & 2.7 & 7 \\
\hline & $\operatorname{Max}$ & 156.3 & 5 & 7.5 & 16.1 \\
\hline & Average & 127.08 & 3.6 & 4.91 & 12.64 \\
\hline \multirow{3}{*}{$\begin{array}{l}\text { Jasper veins } \\
\quad(n=7)\end{array}$} & Mini & 174.9 & 4.3 & 4.8 & 21.8 \\
\hline & Max & 238.9 & 5.5 & 8 & 31.8 \\
\hline & Average & 207.4 & 4.78 & 6.7 & 26.8 \\
\hline \multirow{3}{*}{$\begin{array}{l}\text { Pegmatite veins } \\
\qquad(n=6)\end{array}$} & Mini & 87.3 & 2.6 & 2.8 & 5.2 \\
\hline & Max & 116 & 3.1 & 7.5 & 7.9 \\
\hline & Average & 95.32 & 2.87 & 4.32 & 6.50 \\
\hline
\end{tabular}

$(\mathrm{n})=$ number of measurements, Mini $=$ Minimum, Maxi $=$ Maximum.

\section{Ore Microscopic Studies}

The opaque minerals have been studied in details using ore microscope. Six samples from hornblende schist, metadacite and diorite rocks were selected and prepared as polished sections for the intensive study of opaque minerals. The most important opaque minerals recorded are gold, pyrite and goethite.

Gold occurs as fine minute speaks (Figure 12) in all studied samples and associated with pyrite. Pyrite is recorded in all of the studied samples. It is either found as medium to coarse-grained cubic crystals (Figure 13) or as very fine-grained inclusions embedded within the large quartz crystals; most crystals are idiomorphic to sub-idiomorphic and mainly square-shaped grains. Some pyrite crystals are partially to completely altered to goethite (Figure 14).

Goethite is found as euhedral cubes and pseudomorphs after pyrite disseminated in quartz due to oxidation and hydration processes. Occasionally, goethite crystals are showing concentric curved manner forming colloform texture (Figure 15).

\section{Mineralogical Features}

The heavy minerals were separated using heavy liquid (bromoform) separation 


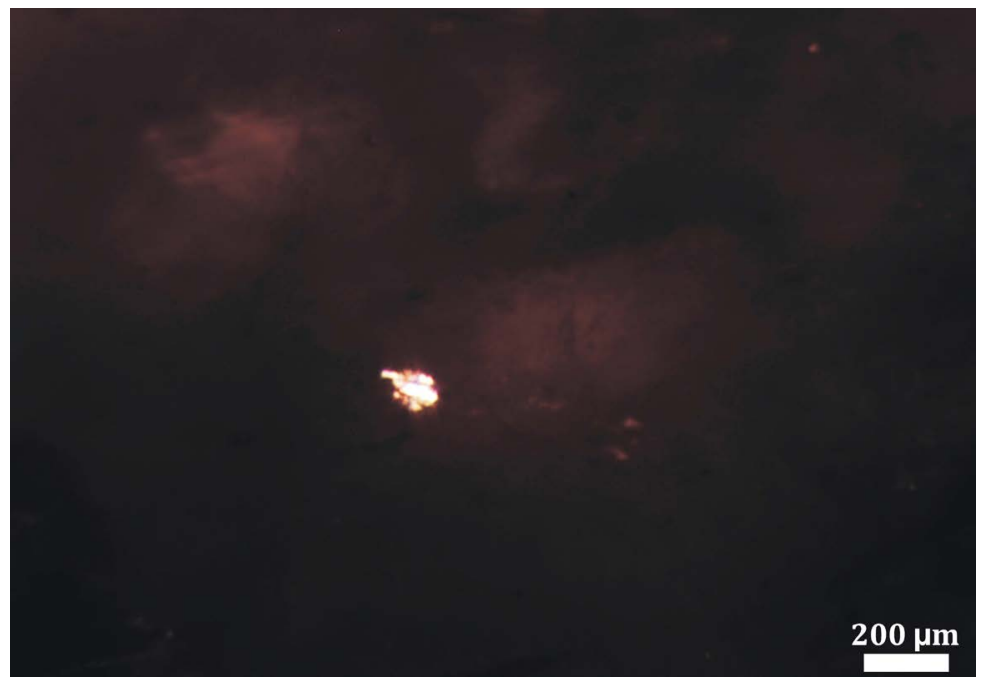

Figure 12. Photomicrograph showing speaks of gold, (C.N).

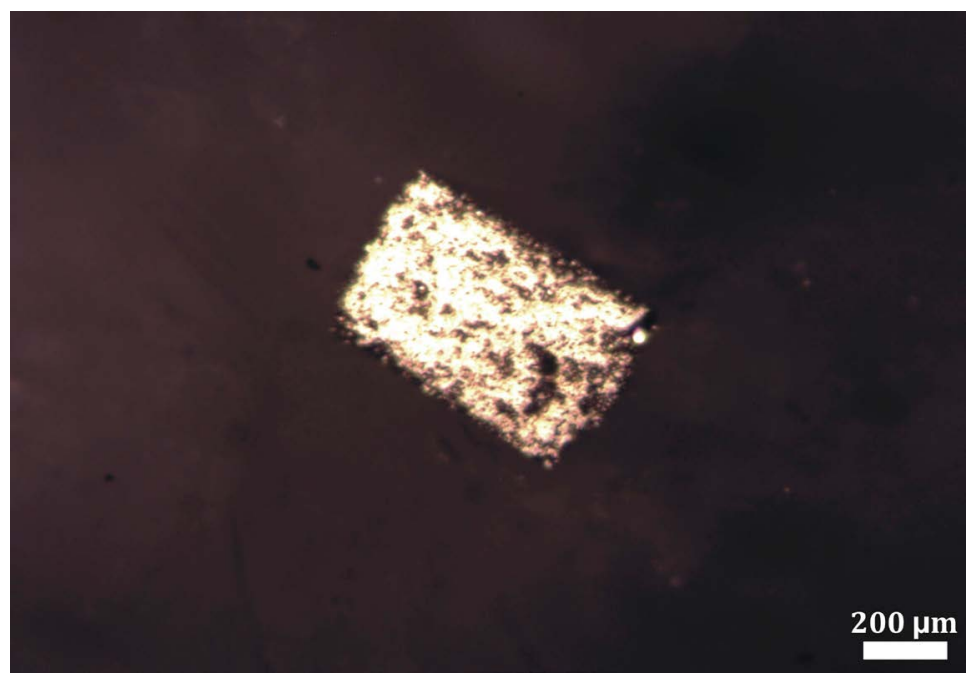

Figure 13. Photomicrograph showing cubic crystal of euhedral pyrite, (C.N).

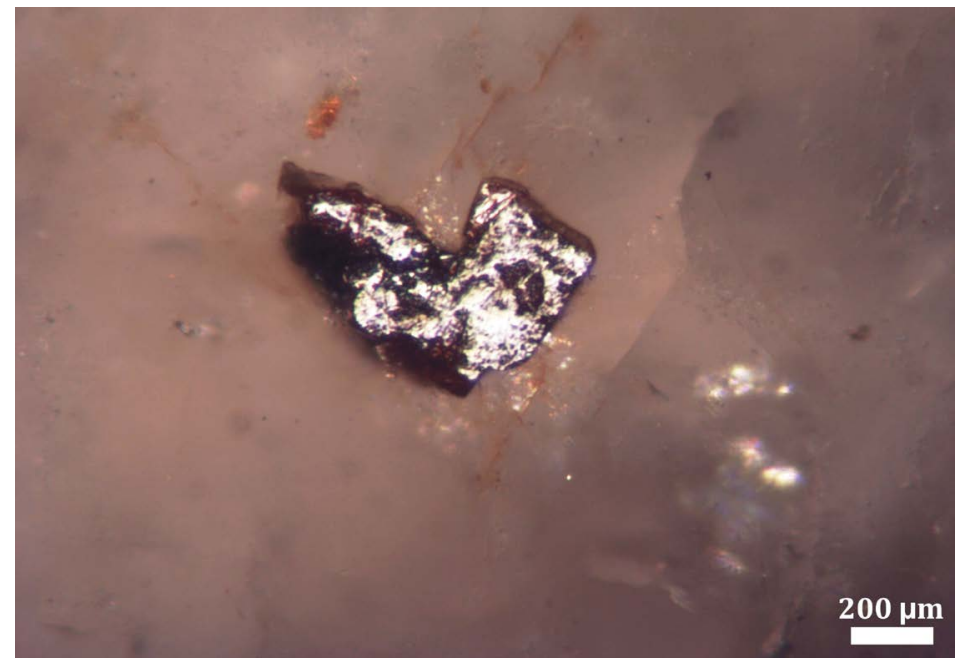

Figure 14. Photomicrograph showing pyrite partly altered to goethite, (C.N). 


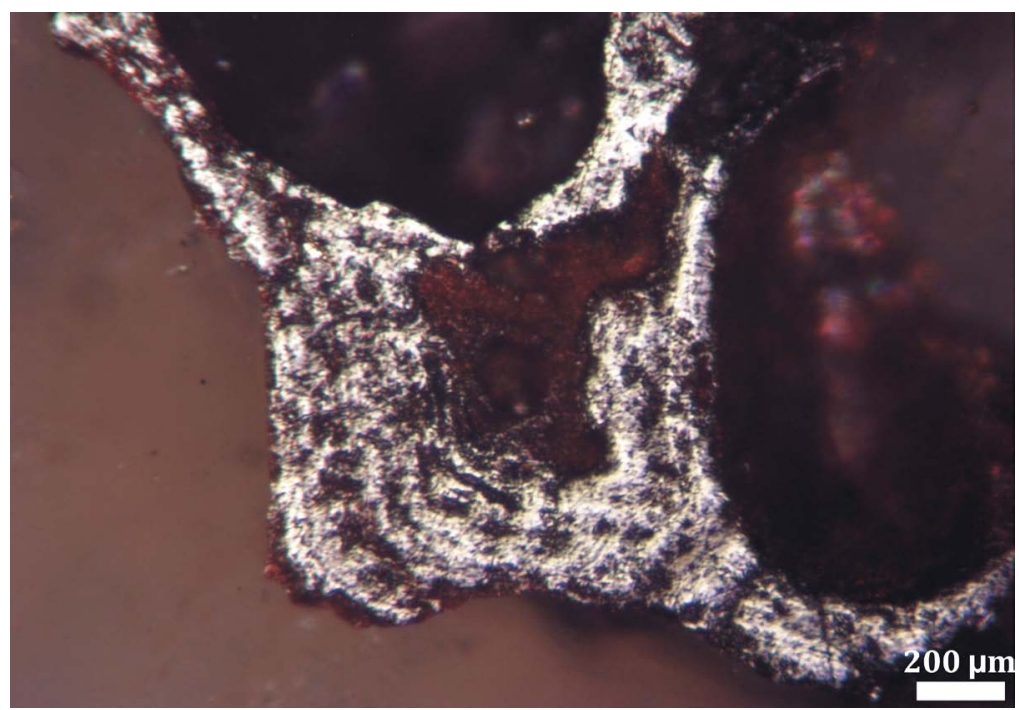

Figure 15. Photomicrograph showing colloform texture of goethite after pyrite, (C.N).

technique from three different representative samples (hornblende schist, metadacite and diorite rocks), followed by magnetic fractionation using Frantz isodynamic separator. The heavy minerals were picked under a binocular microscope and identified by Scanning Electron Microscope, energy dispersive spectrometry (SEM-EDX) technique at Laboratories of Nuclear Materials Authority (NMA), Cairo, Egypt.

The identified minerals in the different rock types will discuss in the following paragraphs.

\subsection{Gold [Au]}

Gold commonly occurs as native Au intimately associated with arsenopyrite, the sulpho-salts or as isolated grains. Experiments have demonstrated that $\mathrm{Au}$ is hosted in sulfide minerals with the following decreasing order of Au concentration: bornite $>$ chalcopyrite $>$ pyrrhotite $>$ pyrite [37] [38] [39].

Yang et al. (2006) [40] demonstrated that Au concentrations in pyrite within granite can range from $<0.02$ to $21 \mathrm{ppm}$. In the study area, gold is present as individual fine-grained crystals associated with pyrite. It is recorded in hornblende schist, metadacite and diorite rocks for the first time in the study area and confirmed by Scanning Electron Microscope, energy dispersive spectrometry (SEM-EDX) technique and contains $(18.32 \% \mathrm{Au}),(39.50 \% \mathrm{Au}),(60.42 \% \mathrm{Au})$ respectively. In both hornblende schist and metadacite, gold associated with silver and copper (Figure 16(a) and Figure 16(b)), whereas in diorite rock, gold associated with copper (Figure 16(c)).

\subsection{Pyrite $\left[\mathrm{FeS}_{2}\right]$}

It occurs as cubes, octahedral, or a combination of these forms and crystallized in cubic system. The oxidized form of pyrite is unstable and decomposed into insoluble iron hydroxide and free sulfuric acid, which passes into solution. It is 


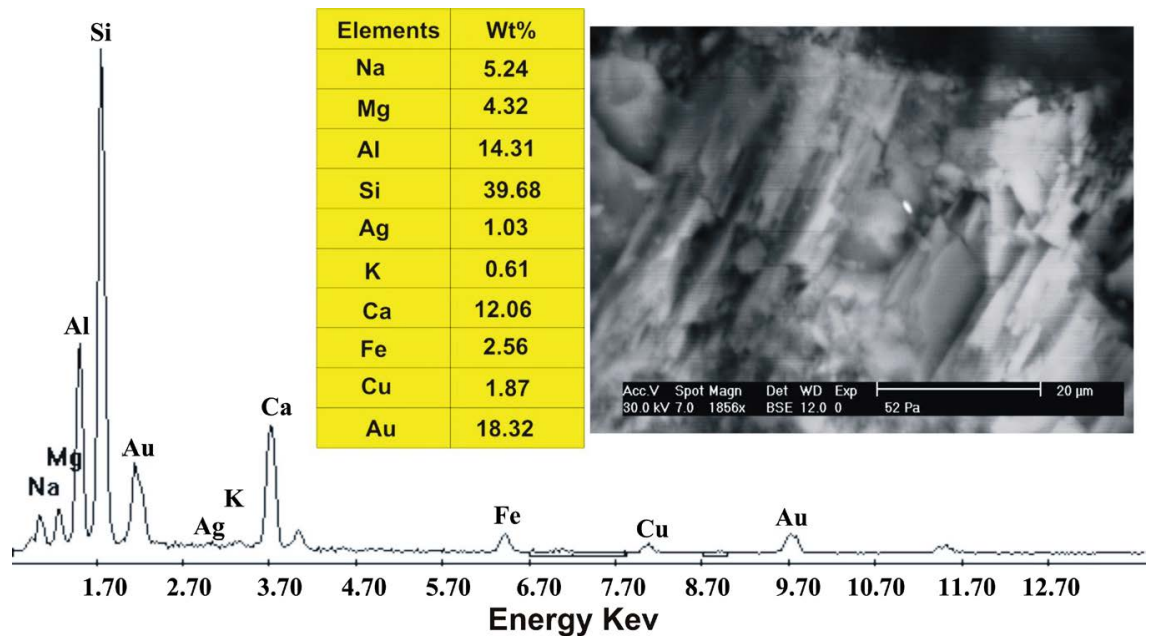

(a)

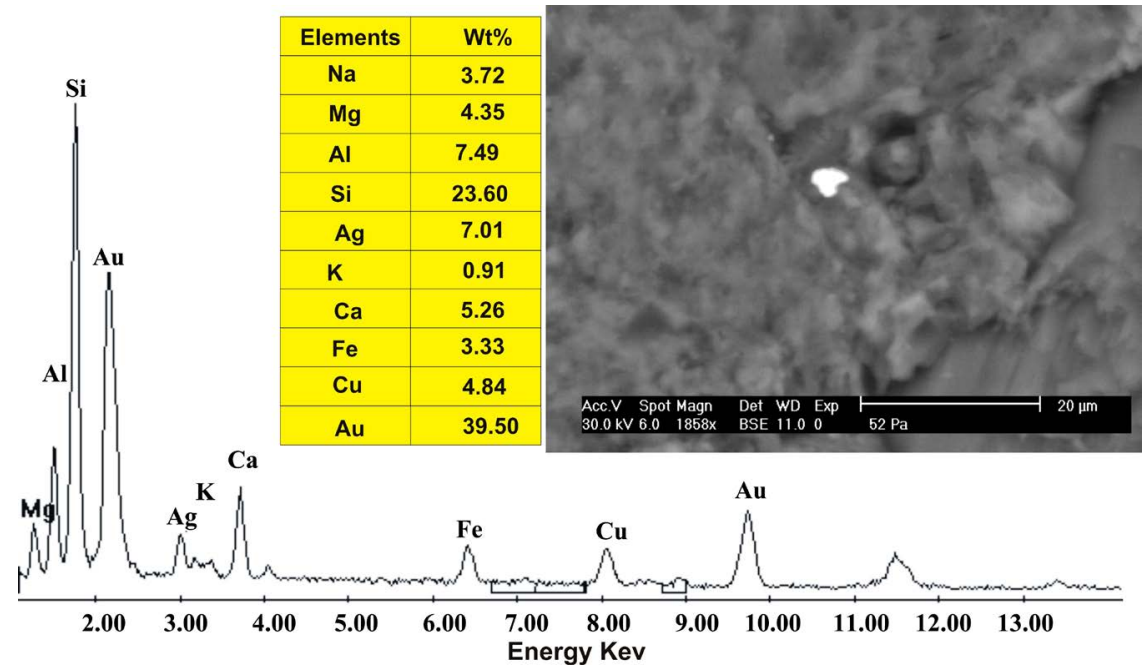

(b)

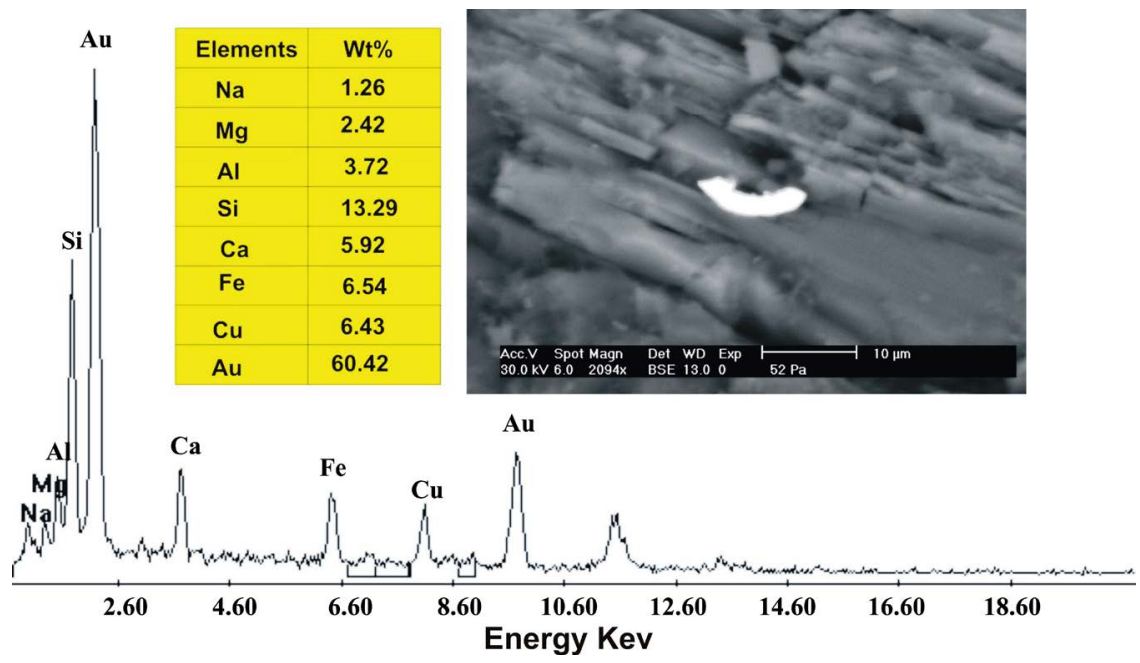

(c)

Figure 16. (a) SEM backscattered data and image of gold in hornblende schist rock. (b) SEM backscattered data and image of gold in metadacite rock. (c) SEM backscattered data and image of gold in diorite rock. 
mainly used in the production of sulfuric acid and sometimes used as a gold ore when it contains fine dispersion of gold. It is confirmed in hornblende schist, metadacite and diorite rocks by (SEM-EDX) technique and contains $(50.26 \% \mathrm{Fe}$, $49.74 \% \mathrm{~S}),(45.47 \% \mathrm{Fe}, 34.38 \% \mathrm{~S}),(44.29 \% \mathrm{Fe}, 35.84 \% \mathrm{~S})$ respectively (Figures $17(\mathrm{a})-(\mathrm{c}))$.

\subsection{Hemimorphite $\left[\mathrm{Zn}_{4}\left(\mathrm{Si}_{2} \mathrm{O}_{7}\right)(\mathrm{OH})_{2} \cdot \mathrm{H}_{2} \mathrm{O}\right]$}

Hemimorphite is an important ore of zinc and contains up to $54.2 \%$ of the metal, together with silicon, oxygen and hydrogen. It is most commonly forms crystalline crusts and layers, also massive, granular, rounded and reniform aggregates, concentrically striated, or finely needle-shaped, fibrous or stalactitic, and rarely fan-shaped clusters of crystals. It is confirmed in hornblende schist by (SEM-EDX) technique and contains $47.77 \% \mathrm{Zn}, 25.02 \% \mathrm{Si}, 7.78 \% \mathrm{Mg}$ and $6.04 \%$ $\mathrm{Ca}$ (Figure 18).

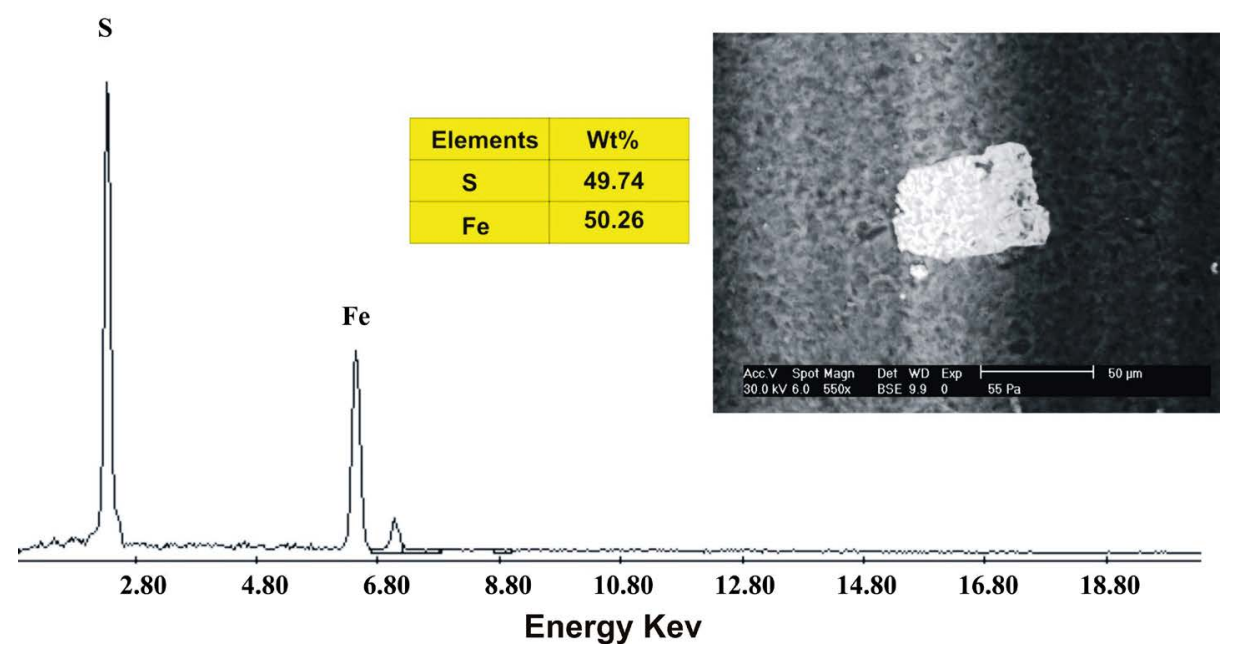

(a)

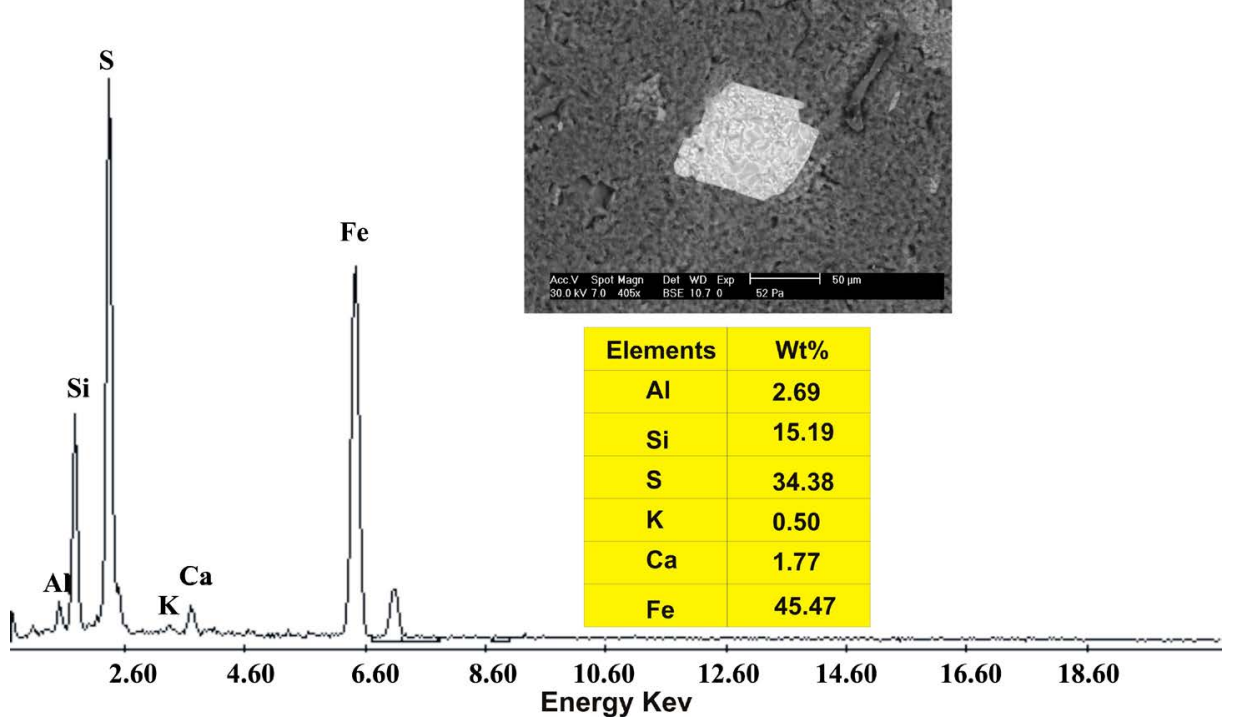

(b) 


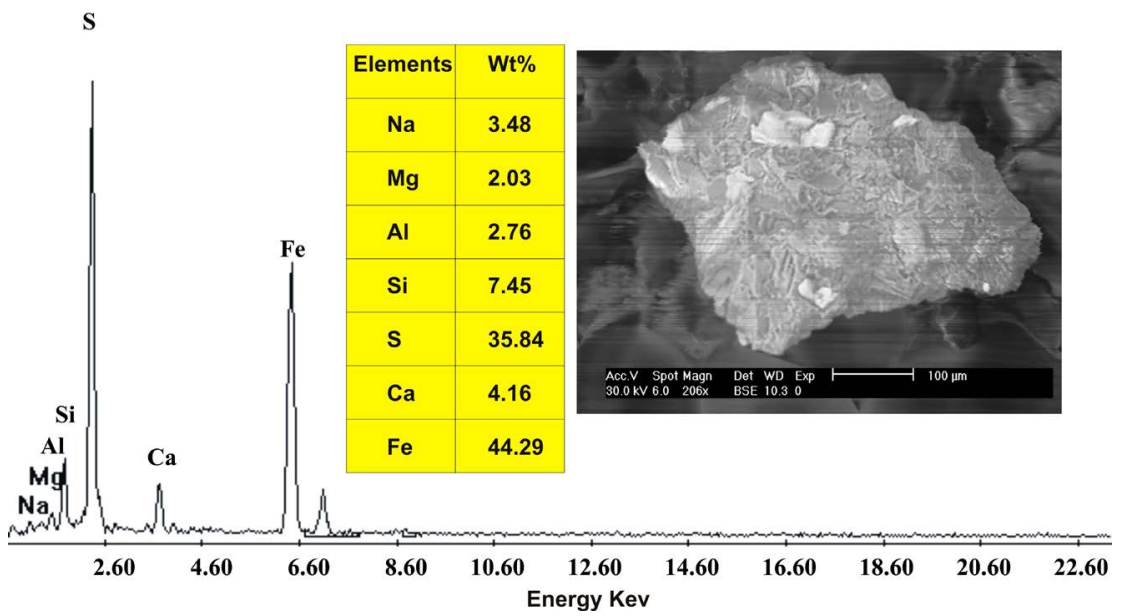

(c)

Figure 17. (a) SEM backscattered data and image of pyrite in hornblende schist rock. (b) SEM backscattered data and image of pyrite in metadacite rock. (c) SEM backscattered data and image of pyrite in diorite rock.

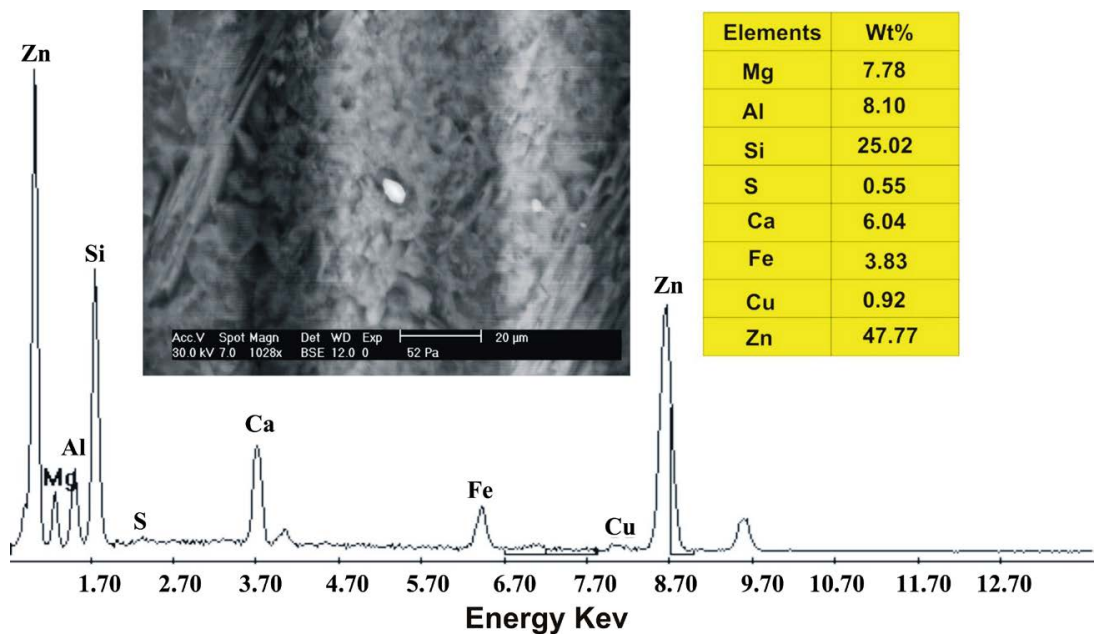

Figure 18. SEM backscattered data and image of hemimorphite in hornblende schist rock.

\subsection{Zircon $\left[\mathrm{ZrSiO}_{4}\right]$}

Zircon varies in shape from euhedral, subhedral to rounded crystals and most of zircon crystals are bipyramidal muddy and varies in colour from colourless, brown, grey, yellow and red with variable sizes. It is confirmed in metadacite by (SEM-EDX) technique and contains $67.04 \% \mathrm{Zr}, 22.82 \% \mathrm{Si}$ and $4.22 \% \mathrm{Hf}$ (Figure 19).

\subsection{Ilmenite $\left[\mathrm{FeTiO}_{3}\right]$}

Ilmenite is the most important ore of titanium and used as a raw material for pigment production. It occurs as thick tabular grains, angular to sub-angular and confirmed in diorite rocks by (SEM-EDX) technique and contains $47.06 \%$ $\mathrm{Fe}, 32.98 \% \mathrm{Ti}$ and $13.07 \% \mathrm{Si}$ (Figure 20). 


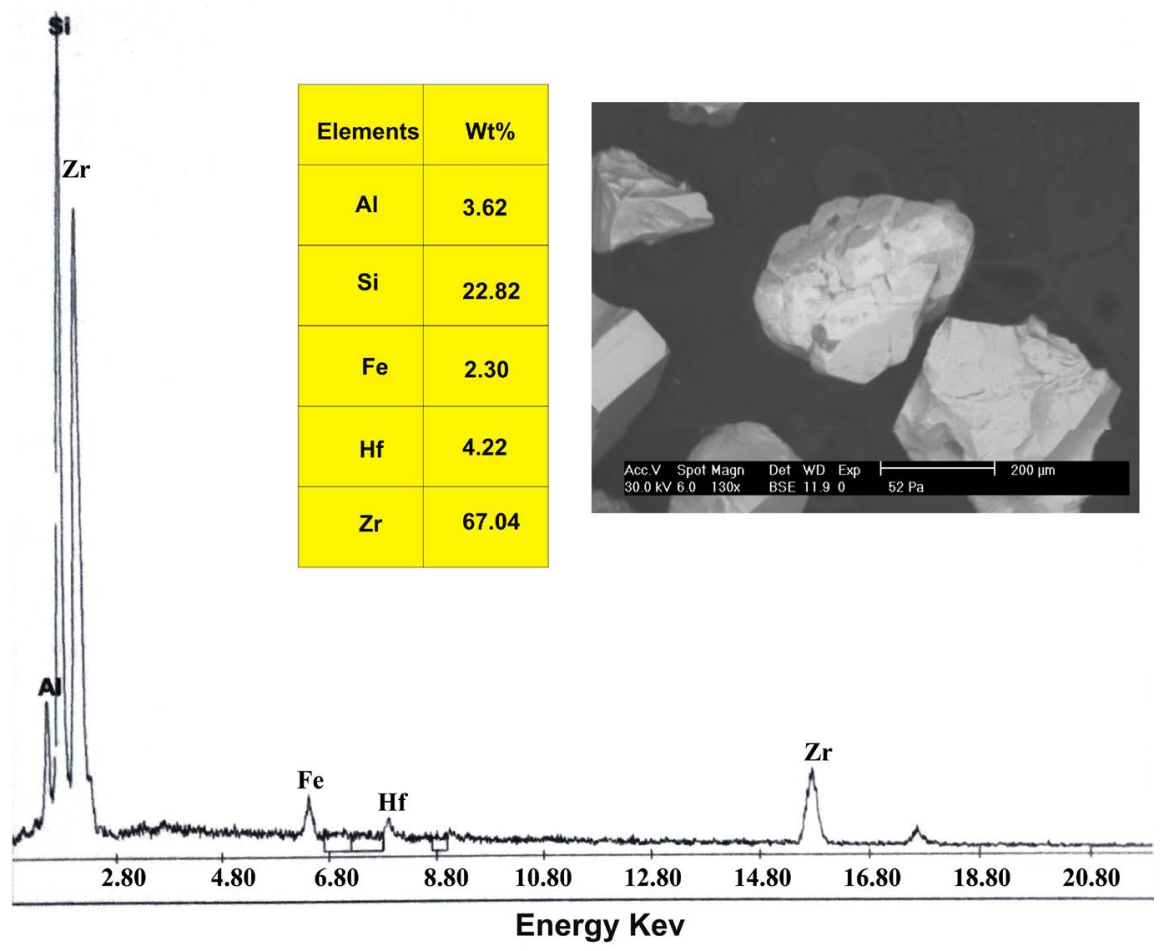

Figure 19. SEM backscattered data and image of zircon in metadacite rock.

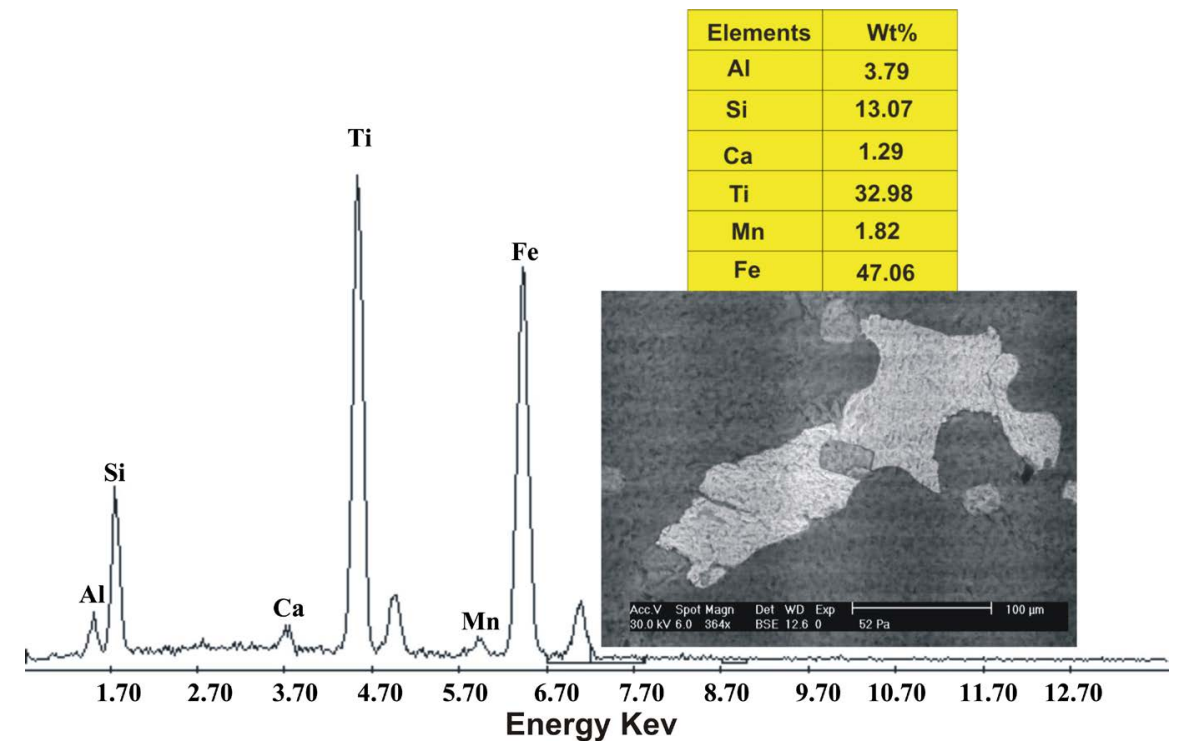

Figure 20. SEM backscattered data and image of ilmenite in diorite rock.

\subsection{Barite $\left[\mathrm{BaSO}_{4}\right]$}

It is the principal ore for barium and it is used in paint and drilling mud due to its high specific gravity and also is used as radiation isolated material in nuclear industry. It displays colourless to white grains with vitreous luster. It was confirmed in diorite rocks by (SEM-EDX) technique and contains $50.76 \%$ Ba, $14.98 \% \mathrm{~S}, 9.45 \% \mathrm{Fe}$ and $5.18 \% \mathrm{Ca}$ (Figure 21 ). 


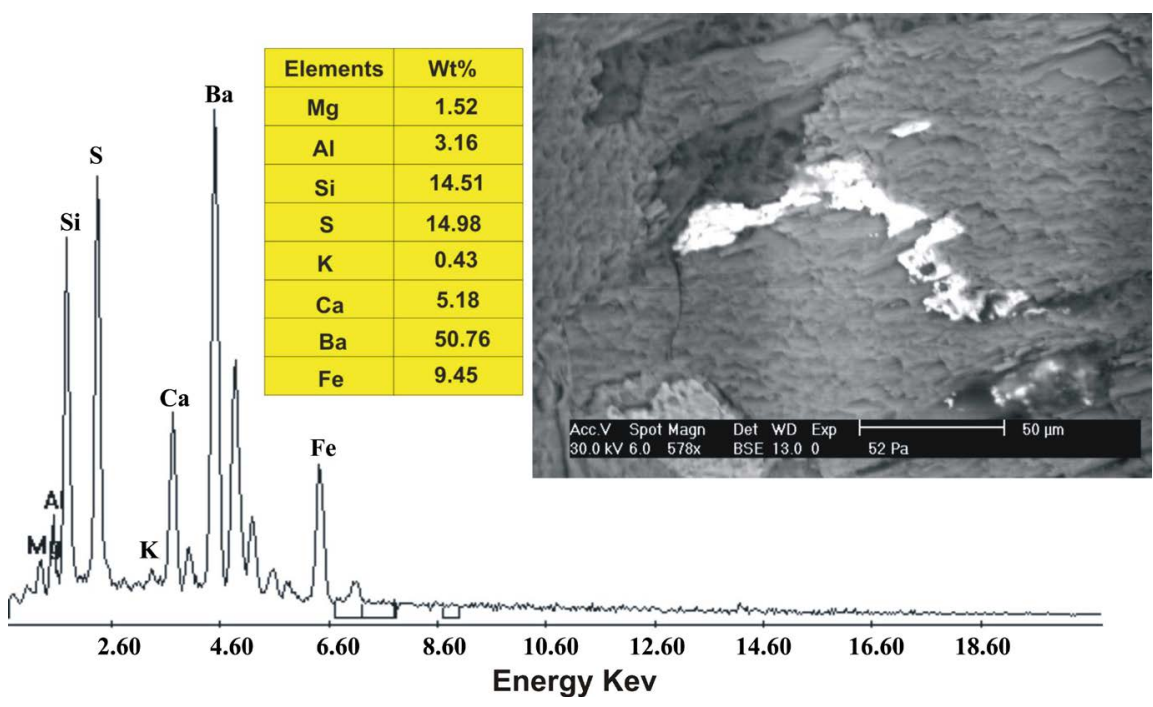

Figure 21. SEM backscattered data and image of barite in diorite rock.

\section{Gold Fire Assay}

Fire assaying is the oldest and most reliable method of determining gold in rock or concentrate samples.

On the light of the presence of gold detected during the mineralogical and SEM techniques in alteration samples of metasediments-metavolcanics association and diorite rocks. This result led to analysis of bulk samples of them using fire assay technique at the Central Laboratories of the Egyptian Mineral Resources Authority (EMRA).

Six samples (two from hornblende schist, two from metadacite and two from diorite rocks were analyzed for gold content, using the fire assay method. The gold content in hornblende schist ranges between 0.8 and $1 \mathrm{ppm}$ with an average of 0.9 , whereas in metadacite ranges from 0.7 to $1.1 \mathrm{ppm}$ with an average of 0.9 $\mathrm{ppm}$. The concentration of gold increased in diorite rock and ranges between 0.9 and 1.1 with an average of $1 \mathrm{ppm}$ (Table 2).

\section{Discussion}

The present study discusses a new occurrence of gold in metasediments-metavolcanics association and also in diorite rocks in the eastern side of W. El Gemal.

Hume (1937) [1] assumed that gold mineralization is an integral part of hydrothermal activities related to diorite intrusions of the Proterozoic age. From this point of view, the rocks in the eastern side of W. El Gemal are metasediments-metavolcanics association intruded by diorite rocks (source of gold). Both of metasediments-metavolcanics association and diorite rocks were intruded by granodiorite rocks that may act as a source for a hydrothermal solutions ascending along fractures of all older rocks. During this stage, a chemical reaction of hydrothermal fluids ( $\mathrm{pH}$ between 3.5 and 5) with metasediments-metavolcanics association and diorite rocks to form sericite and increased 
Table 2. Gold fire assay data for the different rock types, W. El Gemal area, SED, Egypt.

\begin{tabular}{cccc}
\hline S. No. & Rock type & Au concentration $(\mathrm{ppm})$ & Average \\
\hline Hb1 & Hornblende schist & 1.0 & 0.9 \\
$\mathrm{Hb2}$ & & 0.8 & \\
$\mathrm{Md} 1$ & Metadacite & 0.7 & 0.9 \\
$\mathrm{Md} 2$ & & 1.1 & \\
$\mathrm{D} 1$ & Diorite rock & 1.1 & 1.0 \\
$\mathrm{D} 2$ & & 0.9 & \\
\hline
\end{tabular}
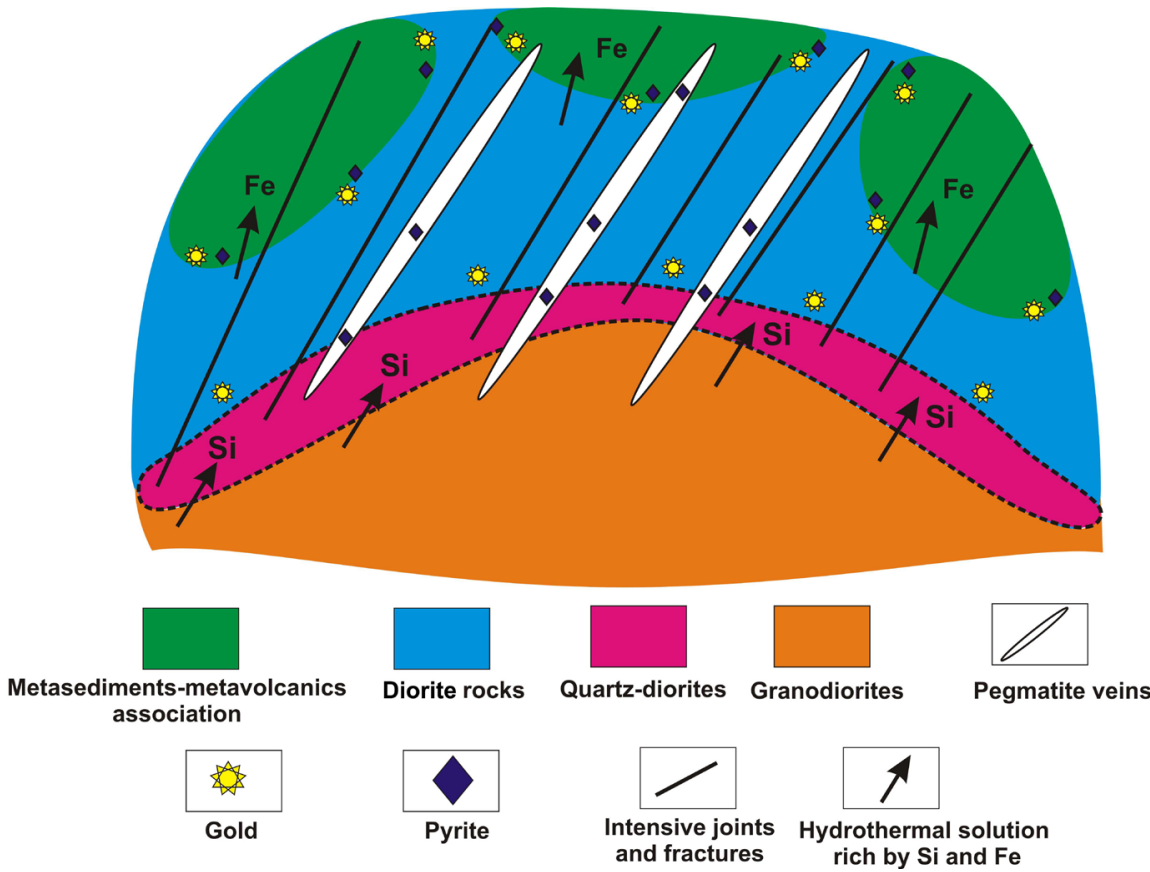

Figure 22. Sketch diagram showing the successive events of enrichment of metasediments-metavolcanics association and the diorite rocks by pyrite and gold mineralization.

of silica content. The enrichment of silica content led to the formation of quartz-diorite rocks. Iron derived from the host rocks and sulfur from the hydrothermal fluids could form pyrite while the gold was precipitated at the contact between metasediments-metavolcanics association and diorite rocks (Figure 22). This contact may call as alteration zone. Alterations accompanying deposition of gold, on the other hand, constitute a good target for gold. The alteration zones around the mineralized veins are of economic interest as they contain reasonably high gold values ([41] [42]) and could be considered as new target for disseminated gold in the Eastern Desert of Egypt [42]. From the field observation, the gold concentrated along the main northeast-southwest (NE-SW) structural trend suggests that gold dispersion in the studied area is structurally controlled.

\section{Conclusions and Recommendations}

The basement rocks exposed in the eastern part of W. El Gemal area are 
metasediments-metavolcanics association, diorite rocks, older granitoids (granodiorite) and younger granites (syenogranites). Finally these rocks are invaded by pegmatite and basic dykes as well as quartz veins. The radioactivity of this area is weak, where the average eU contents in metasediments-metavolcanics association, diorite rocks, granodiorites, syenogranites, pegmatites and jasper veins are $2.8 \mathrm{ppm}, 1.9 \mathrm{ppm}, 3.26 \mathrm{ppm}, 4.91 \mathrm{ppm}, 4.32 \mathrm{ppm}$ and $6.7 \mathrm{ppm}$ respectively.

The ore microscopy for hornblende schist, metadacite and diorite rocks revealed the existence of gold, pyrite and goethite. The Scanning Electron Microscope (SEM) technique approved the presence of gold, pyrite, hemimorphite, zircon, barite and ilmenite. The results of fire assay for six samples (two from hornblende schist, two from metadacite and two from diorite rocks are $0.9 \mathrm{ppm}$, $0.9 \mathrm{ppm}$ and $1.0 \mathrm{ppm}$ respectively.

The metasediments-metavolcanics association is intruded by diorite rocks (source of gold). Both of metasediments-metavolcanics associations and diorite rocks were intruded by granodiorite rocks that may have acted as a source for hydrothermal solutions ascending along fractures of all older rocks. During this stage, a chemical reaction of hydrothermal fluids ( $\mathrm{pH}$ between 3.5 and 5) with metasediments-metavolcanics association and diorite rocks lead to forming sericite and increasing of silica content. The increase of silica content led to the formation of quartz-diorite rocks. Iron derived from the host rocks and sulfur from the hydrothermal fluids could have formed pyrite while the gold was precipitated at the contact between metasediments-metavolcanics association and diorite rocks.

From the previous data, this area is very promising and needs further detailed studies; e.g. sampling at grid pattern for heavy liquid separation and fire assay analysis.

\section{Acknowledgements}

I would like to express my thanks to Prof. Dr. Ahmed El Metwally, Prof. Dr. Abdu A. El-Sayed, Prof. Dr. Gehad M. Saleh and Prof. Dr. Ismail Abdel Ghani for their helpful comments and suggestions.

\section{Conflicts of Interest}

The author declares no conflicts of interest regarding the publication of this paper.

\section{References}

[1] Hume, W.F. (1937) The Fundamental Pre-Cambrian Rocks of Egypt and the Sudan Their Distribution Age and Character the Minerals of Economic Value Associated with the Intrusive Precambrian Igneous Rocks. Annals of the Geological Survey of Egypt, 2, 689-990.

[2] Amin, M.S. (1955) Geological Features of Some Mineral Deposits in Egypt. Bulletin De Institute du Desert, Egypt, 1, 208-239. 
[3] El Shazly, E.M. (1957) Classification of Egyptian Mineral Deposits. The Egyptian Journal of Geology, 1, 1-20.

[4] Sabet, A.H., Tscgoev, V.B., Bordonosov, V.P., Babourin, L.M., Zalata, A.A. and Francis, M.H. (1976) On Gold Mineralization in the Eastern Desert of Egypt. Annals of the Geological Survey of Egypt, 6, 201-212.

[5] Botros, N.S. (1991) Geological and Geochemical Studies on Some Gold Occurrences in the North Eastern Desert, Egypt. Ph.D. Thesis, Zagazig Univ., Zagazig, 146.

[6] Botros, N.S. (1995) Genesis of Gold Mineralization in the North Eastern Desert, Egypt. Annals of the Geological Survey of Egypt, 10, 381-409.

[7] Sabet, A.H. and Bordonosov, V.P. (1984) The Gold Ore Formations in the Eastern Desert of Egypt. Annals of the Geological Survey of Egypt, 16, 35-42.

[8] Harraz, H.Z. (1995) Primary Geochemical Haloes, El Sid Gold Mine, Eastern Desert, Egypt. Journal of African Earth Sciences, 20, 61-71. https://doi.org/10.1016/0899-5362(95)00045-U

[9] El-Makky, A.M. (2011) Statistical Analysis of La, Ce, Nd, Y, Nb, Ti, P, and Zr in Bedrocks and Their Significance in Geochemical Exploration at the Um Garayat Gold Mine Area, Eastern Desert, Egypt. Natural Resources Research, 20, 157-176. https://doi.org/10.1007/s11053-011-9144-2

[10] Harraz, H.Z. and Hamdy, M.M. (2015) Zonation of Primary Haloes of Atud Auriferous Quartz Vein Deposit, Central Eastern Desert of Egypt: A Potential Exploration Model Targeting for Hidden Mesothermal Gold Deposits. Journal of African Earth Sciences, 101, 1-18. https://doi.org/10.1016/j.jafrearsci.2014.09.001

[11] Groves, D.I., Goldfarb, R.J., Gebre-Mariam, M., Hagemann, S.G. and Robert, F. (1998) Orogenic Gold Deposits: A Proposed Classification in the Context of Their Crustal Distribution and Relationship to Other Gold Deposit Types. Ore Geology Reviews, 13, 7-27. https://doi.org/10.1016/S0169-1368(97)00012-7

[12] Goldfarb, R.J., Groves, D.I. and Gardoll, S. (2001) Orogenic Gold and Geologic Time: A Global Synthesis. Ore Geology Reviews, 18, 1-75. https://doi.org/10.1016/S0169-1368(01)00016-6

[13] Goldfarb, R.J., Baker, T., Dube, B., Groves, D.I., Hart, C.J. and Gosselin, P. (2005) Distribution Character and Genesis of Gold Deposits in Metamorphic Terranes. In: Hedenquist, J.W., Thompson, J.F.H., Goldfarb, R.J. and Richards, J.P., Eds., Economic Geology 100 th Anniversary Volume, Society of Economic Geologists, Littleton, Colorado, USA, 407-450. https://doi.org/10.5382/AV100.14

[14] Khalil, I.K., Moghazi, A.M. and El Makky, A.M. (2016) Nature and Geodynamic Setting of Late Neoproterozoic Vein-Type Gold Mineralization in the Eastern Desert of Egypt: Mineralogical and Geochemical Constraints. In: Bouabdellah, M. and Slack, J.F., Eds., Mineral Deposits of North Africa, Springer-Verlag, Berlin-Heidelberg, 353-370. https://doi.org/10.1007/978-3-319-31733-5 14

[15] Loizenbauer, J. and Neumayr, P. (1996) Structural Controls on the Formation of the Fawakhir Gold Mine, EL Sid-Eastern Desert, Egypt: Tectonic and Fluid Inclusion Evidence. Proceedings Geological Survey of Egypt Centennial Conference, Cairo, 477-488.

[16] Kusky, T.M. and Ramadan, T.M. (2002) Structural Controls on Neoproterozoic Mineralization in the South Eastern Desert, Egypt: An Integrated Field, Landsat TM, and SIRC/X SAR Approach. Journal of African Earth Sciences, 35, 107-121. https://doi.org/10.1016/S0899-5362(02)00029-5

[17] Botros, N.S. (2004) A New Classification of the Gold Deposits of Egypt. Ore Geolo- 
gy Reviews, 25, 1-37. https://doi.org/10.1016/j.oregeorev.2003.07.002

[18] Helmy, H.M., Kaindl, R., Fritz, H. and Loizenbauer, J. (2004) The Sukari Gold Mine, Eastern Desert, Egypt: Structural Setting, Mineralogy, and Fluid Inclusion Study. Mineral Deposita, 39, 495-511. https://doi.org/10.1007/s00126-004-0426-Z

[19] Zoheir, B.A. (2011) Transpressional Zones in Ophiolitic Mélange Terranes: Potential Exploration Targets for Gold in the South Eastern Desert, Egypt. Journal of Geochemical Exploration, 111, 23-38. https://doi.org/10.1016/j.gexplo.2011.07.003

[20] Zoheir, B.A., Emam, A., El-Amawy, M. and Abu-Alam, T. (2018) Auriferous Shear Zones in the Central Allaqi-Haiani Belt: Orogenic Gold in Post-Accretionary Structures, SE Egypt. Journal of African Earth Sciences, 146, 118-131. https://doi.org/10.1016/j.jafrearsci.2017.10.017

[21] Takla, M.A., El Dogdoug, A.A., Rasmy, A.H., Gad, M.A. and El Tabbal, H. (1990) Origin of Um Eliega Gold Mineralization, South Eastern Desert, Egypt. European Journal of Mineralogy, 2, 3-20.

[22] Harraz, H.Z. (2000) A Genetic Model for a Mesothermal Au Deposit: Evidence from Fluid Inclusions and Stable Isotopic Studies at El-Sid Gold Mine, Eastern Desert, Egypt. Journal of African Earth Sciences, 30, 267-282.

https://doi.org/10.1016/S0899-5362(00)00019-1

[23] Botros, N.S. (2002) Metallogeny of Gold in Relation to the Evolution of the Nubian Shield in Egypt. Ore Geology Reviews, 19, 137-164.

https://doi.org/10.1016/S0169-1368(01)00035-X

[24] Khalil, I.K., Helba, H.A. and Mucke, A. (2003) Genesis of the Gold Mineralization at the Dungash Gold Mine Area, Eastern Desert, Egypt: A Mineralogical-Microchemical Study. Journal of African Earth Sciences, 37, 111-122. https://doi.org/10.1016/S0899-5362(02)00155-0

[25] Zoheir, B.A. and Akawy, A. (2010) Genesis of the Abu Marawat Gold Deposit, Central Eastern Desert of Egypt. Journal of African Earth Sciences, 57, 306-320. https://doi.org/10.1016/j.jafrearsci.2009.10.002

[26] El-Makky, A.M., Khalil, K.I. and Ibrahim, I.M. (2012) Hydrothermal Wall Rock Alteration at Kurdeman Gold Mine Area, Eastern Desert, Egypt. Neues Jahrbuch für Mineralogie-Abhandlungen, 189, 75-95. https://doi.org/10.1127/0077-7757/2012/0210

[27] Helmy, H.M. and Zoheir, B.A. (2015) Metal and Fluid Sources in a Potential World-Class Gold Deposit: El-Sid Mine, Egypt. International Journal of Earth Sciences, 104, 645-661. https://doi.org/10.1007/s00531-014-1094-6

[28] Abd El-Wahed, M.A., Harraz, H. and El-Behairy, M.H. (2016) Transpressional Imbricate Thrust Zones Controlling Gold Mineralization in the Central Eastern Desert of Egypt. Ore Geology Reviews, 78, 424-446. https://doi.org/10.1016/j.oregeorev.2016.03.022

[29] Zoheir, B., Abd El-Wahed, M., Beiranvand Pour, A. and Abdelnasser, A. (2019) Orogenic Gold in Transpression and Transtension Zones: Field and Remote Sensing Studies of the Barramiya-Mueilha Sector, Egypt. Remote Sensing, 11, 2122. https://doi.org/10.3390/rs11182122

[30] Hegazy, H.M. (1984) Geology of Wadi El-Gemal Area, Eastern Desert, Egypt. Ph.D. Thesis, Assiut University, Assiut, 271.

[31] El Maghraby, A.M.O. (1994) Geology, Petrology, and Geochemistry of the Pre Cambrian Rocks between Wadi Ghadir and Wadi El-Gemal, Eastern Desert, Egypt. Ph.D. Thesis, Faculty of Science, Cairo University, Cairo, 226.

[32] Akawy, A.A. (1999) Structural Analysis of the Basement Complex in Wadi El Gemal 
Area, South Eastern Desert, Egypt. Ph.D. Thesis, South Valley University, Qena, 346.

[33] Shimron, A.E. (1980) Proterozoic Island Arc Volcanism and Sedimentation in Sinai. Precambrian Research, 12, 437-458. https://doi.org/10.1016/0301-9268(80)90039-X

[34] Zalata, A.A., Hussein, H.A., El-Metwally, A.A., El-Aassy, I.E. and Ibrahim, M.E. (1993) Petrography and Crustal Evolution of South Central Sinai Massif, Egypt. Mansoura Science Bulletin, 2, 181-200.

[35] Kröner, A., Greiling, R., Reischmann, T., Hussein, I.M., Stern, R.J., Kruger, K., Durr, S. and Zimmer, M. (1987) Pan-African Crustal Evolution in the Nubian Segment of Northeast Africa. In: Kröner, A., Ed., Proterozoic lithospheric Evolution, American Geophysical Union, Geodynamics Series, Vol. 17, 237-257.

[36] Greenberg, J.K. (1981) Characteristics and Origin of Egyptian Younger Granites. Geological Society of America Bulletin, Part I, 92, 224-256. https://doi.org/10.1130/0016-7606(1981)92<224:CAOOEY >2.0.CO;2

[37] Cygan, G.L. and Candela, P.A. (1995) Preliminary Study of Gold Partitioning among Pyrrhotite, Pyrite, Magnetite, and Chalcopyrite in Gold-Saturated Chloride Solutions at 600 to $700{ }^{\circ} \mathrm{C}, 140 \mathrm{MPa}$ (1400bars). In: Thompson, J.F.H., Ed., Magmas, Fluids, and Ore Deposits, Mineralogical Association of Canada Short Course Series, Mineralogical Association of Canada, Ontario, 129-137.

[38] Jugo, P.J., Candela, P.A. and Piccoli, P.M. (1999) Magmatic Sulfides and Au:Cu Ratios in Porphyry Deposits: An Experimental Study of Copper and Gold Partitioning at $850{ }^{\circ} \mathrm{C}, 100 \mathrm{MPa}$ in a Haplogranitic Melt-Pyrrhotite-Intermediate Solid Solution-Gold Metal Assemblage, at Gas Saturation. Lithos, 46, 573-589. https://doi.org/10.1016/S0024-4937(98)00083-8

[39] Simon, G., Kesler, S.E. and Essene, E.J. (2000) Gold in Porphyry Copper Deposits: Experimental Determination of the Distribution of Gold in the Cu-Fe-S System at 400 to $700{ }^{\circ}$ C. Economic Geology, 95, 259-270. https://doi.org/10.2113/gsecongeo.95.2.259

[40] Yang, X.M., Lentz, D.R. and Sylvester, P.J. (2006) Gold Contents of Sulphide Minerals in Granitoids from Southwestern New Brunswick, Canada. Mineralium Deposita, 41, 369-386. https://doi.org/10.1007/s00126-006-0065-7

[41] Osman, A.M. and Dardir, A.A. (1989) On the Mineralogy and Geochemistry of Some Gold-Bearing Quartz Veins in the Central Eastern Desert of Egypt and Their Altered Wall Rocks. Annals of the Geological Survey of Egypt, 21, 17-25.

[42] Botros, N.S. (1993) New Prospects for Gold Mineralization in Egypt. Annals of the Geological Survey of Egypt, 19, 47-56. 